\title{
RECURSO DE AMPARO FRENTE A DECISIONES DEL LETRADO DE LA ADMINISTRACIÓN DE JUSTICIA NO SUJETAS A CONTROL JURISDICCIONAL
}

\author{
Recurso de amparo against Court Clerk's Procedural \\ Decisions out of Jurisdiccional Control
}

\author{
BELÉN DEL POZO SIERRA \\ Universidad CEU San Pablo \\ belen.pozosierra@ceu.es
}

Cómo citar/Citation

Del Pozo Sierra, B. (2016).

Recurso de amparo frente a decisiones del letrado de la Administración de Justicia no sujetas a control jurisdiccional

Derecho Privado y Constitución, 30, 177-219.

doi: http://dx.doi.org/10.18042/cepc/dpc.30.04

(Recepción: 30/06//2016; aceptación después de la revisión: 14/09/2016; publicación: 17/11/2016)

\section{Resumen}

El nuevo papel del letrado de la Administración de Justicia plantea supuestos en los que sus decisiones procesales, en cuestiones relevantes en el marco del proceso contencioso administrativo, se ven excluidas por el legislador del recurso de revisión ante el juez o tribunal (párrafo primero del art. 102 bis.2 LJCA). Resoluciones procesales que por afectar a un derecho fundamental atañen a la potestad jurisdiccional reservada en exclusiva a jueces y magistrados, a quienes compete dispensar la tutela judicial efectiva que a todos garantiza la Constitución española. Supuestos donde siendo objeto de queja en amparo una resolución procesal de quien no es el titular del juzgado tiene difícil encaje en el recurso de amparo contra actos u omisiones judiciales. En STC 58/2016 el Tribunal Constitucional no se limita a expulsar del ordenamiento jurídico un precepto, sino que ejerce de legislador positivo temporal 
estableciendo un régimen transitorio, en tanto el legislador no se pronuncie al respecto, de impugnación no previsto en la ley.

\section{Palabras clave}

Inconstitucionalidad; amparo atípico; letrado de la Administración de Justicia; dilación indebida, legislador positivo.

\section{Abstract}

Some procedural decisions passed by the court clerk are excluded form the fromework of the review before a judge or a court. When these decisions concern the fundamental rights are considered a jurisdictional function. It,s difficult to include these cases within the scope of the amparo against judicial acts or omissions. The Constitutional Court acts like a positive temporary legislator who establishes a transitional system that it,s not foreseen by the law.

\section{Keywords}

Unconstitutionality; atypical application for amparo; court clerk; undue delay. 


\section{SUMARIO}

I. PLANTEAMIENTO GENERAL. II. RECURSOS CONTRA LAS RESOLUCIONES DE LOS LETRADOS DE LA ADMINISTRACIÓN DE JUSTICIA: 1. Resoluciones procesales; 2. Régimen general de recursos frente a resoluciones procesales del letrado de la Administración de Justicia. III. HECHOS DE LOS QUE TRAE CAUSA EL AMPARO. IV. RECURSO DE AMPARO ATÍPICO POR FALTA DE ACTO U OMISIÓN DE ÓRGANO JUDICIAL. ORIGEN “JUDICIAL” DE LA LESIÓN INVOCADA. ART.44.1.b) LOTC: 1. Objeto de queja en amparo; 2. ¿Sería admisible una interpretación amplia del "Órgano Judicial» integrando las resoluciones de quien no es el juez o tribunal?, ¿̇qué actos son actos judiciales?; 3. Recurso de amparo atípico núm. 4577-2011 contra la diligencia de ordenación del letrado de la Administración de Justicia que convocó a las partes para la celebración de la vista del PA 30-2011. V. CUESTIÓN INTERNA DE INCONSTITUCIONALIDAD. VI. DERECHO FUNDAMENTAL A UN PROCESO SIN DILACIONES INDEBIDAS: 1. Dilaciones indebidas consecuencia del señalamiento de la vista a tres años; 2. ¿Concurren los presupuestos de responsabilidad patrimonial de la Administración de Justicia por dilaciones indebidas? VIII. ¿̇PUEDE ENTENDERSE QUE A RAÍZ DE LA SENTENCIA EL TC ACTÚA COMO LEGISLADOR AL ESTABLECER UN NUEVO SISTEMA DE RECURSOS FRENTE A LAS RESOLUCIONES DEL LETRADO DE LA ADMINISTRACIÓN DE JUSTICIA? IX. REFLEXIÓN FINAL. X. BIBLIOGRAFÍA.

\section{PLANTEAMIENTO GENERAL}

Las recientes reformas legislativas de la justicia muestran una clara vocación desjudicializadora que busca eliminar tareas no propiamente jurisdiccionales del ámbito de actuación de los tribunales de justicia, jugando en ello un papel de primer orden por una parte de los integrantes del Cuerpo Superior 
Jurídico de Secretarios Judiciales ${ }^{1}$ y, de otra, los notarios en su calidad de funcionarios públicos titulares de la fe pública judicial o extrajudicial ${ }^{2}$. Así, reza el tenor literal de la exposición de motivos de la LJV 15/2015, de 18 de junio:

De la separación de determinados asuntos del ámbito competencial de los jueces y magistrados sólo cabe esperar, pues, beneficios para todos los sujetos implicados en la jurisdicción voluntaria: para el ciudadano, en la medida en que ello debe tener como consecuencia, cuando precise la actuación del Estado para la actuación de un determinado derecho, una mayor efectividad de sus derechos sin pérdida de garantías; para secretarios judiciales, notarios y registradores de la propiedad y mercantiles, por la nueva dimensión que se les da como servidores públicos, consecuente con su real cualificación técnica y el papel relevante que desempeñan en el tráfico jurídico; y, en último término, para jueces y magistrados, que pueden centrar sus esfuerzos en el cumplimiento de la esencial misión que la Constitución les encomienda, como exclusivos titulares de la potestad jurisdiccional y garantes últimos de los derechos de las personas.

El objetivo final que persigue el legislador, y que inspiró en su día la LEC 1/2000, de 7 de enero, teniendo presente el ámbito en el que nos movemos de funcionamiento de la Administración de Justicia, es que los jueces y magistrados concentren sus esfuerzos en la función que les atribuye la CE, esto es, juzgar y hacer ejecutar lo juzgado. A tal fin, tal y como se recoge en el preámbulo de la Ley 13/2009, de 3 de noviembre, de reforma de la legislación procesal para la implantación de la nueva Oficina Judicial, se busca descargarles de todas aquellas responsabilidades y funciones que no tienen carácter jurisdiccional siendo destinatarias de las mismas los secretarios judiciales. Su implantación y adaptación conlleva una redistribución de competencias entre jueces y secretarios judiciales con la consiguiente reforma de nuestras leyes procesales, tanto en el ámbito civil como en el contencioso ${ }^{3}$, y atribución de funciones a notarios, registradores o secretarios judiciales cuyo límite siempre ha de situarse en la potestad jurisdiccional.

1 Letrados de la Administración de Justicia, tras el cambio de denominación por la LO 7/2015, de 21 de julio.

2 La atribución de nuevas competencias a los notarios y registradores ha provocado la reforma de determinados artículos del Código Civil así como de leyes especiales, por todas citar la LN de 28 de mayo de 1862, LH de 8 de febrero de 1946, LPAP 33/2003, de 3 de noviembre y LRC 20/2011, de 21 de julio.

3 LO 1/2009, de 8 de noviembre, complementaria de la Ley de reforma de la legislación procesal para la implantación de la nueva Oficina Judicial, por la que se modifica la LOPJ 6/1985, de 1 de julio. 
Siendo el objetivo compartido de la reforma de las leyes procesales regular la distribución de competencias entre jueces y tribunales, de un lado, y secretarios judiciales, de otro, se atribuyen a estos últimos, más allá del impulso procesal del procedimiento, competencia tradicional de dicho cuerpo, funciones decisorias en materias colaterales a la función jurisdiccional pero indispensables siempre que no entren en la potestad jurisdiccional. Lo cierto es que tal y como apunta el Consejo General del Poder Judicial, en su informe sobre el anteproyecto de la Ley 13/2009, de reforma de la legislación procesal y de creación de la Oficina Judicial, no estamos ante una reforma novedosa en cuanto a su fondo, pues la ordenación del proceso ya correspondía a los secretarios judiciales. Constituye, sin embargo, una mejora técnica del órgano jurisdiccional al expresar de forma precisa las actuaciones que corresponden a cada autoridad. Son asumibles por el letrado de la Administración de Justicia las actuaciones colaterales al ejercicio de la jurisdicción, especificando la ley que otros actos deben quedar reservados al titular del órgano judicial por su vinculación al ejercicio de la potestad jurisdiccional ${ }^{4}$.

4 «La reforma de la LEC en lo relativo a las funciones de los secretarias judiciales, afecta, en mayor y menor medida, a todas a las que se refieren los arts. 452 y ss. LOP.I.: fe pública judicial, documentación, formación de autos y expedientes, dación de cuenta, impulso procesal en sus distintas modalidades [...].

El anteproyecto plantea, como se ha indicado supra, la necesidad de separar con claridad los ámbitos de actuación de jueces y secretarios judiciales. Esta aclaración de los límites de cada ámbito de actuación fue, en su momento, una de las líneas inspiradoras de la nueva LEC, aprobada por Ley 1/2000, de 7 de enero, que optó por mantener las diligencias de ordenación como expresión de la función que correspondía a los secretarios judiciales en la ordenación del proceso, ampliando su contenido, y suprimió las propuestas de resolución, que habían contribuido a generar un cierto grado de confusión con las funciones judiciales. Como se dice en la EM de la citada ley, las propuestas de resolución, introducidas por la LOPJ, no han servido para aprovechar el indudable conocimiento técnico de los secretarios judiciales, sino más bien para incrementar la confusión entre las atribuciones de estos y las de los tribunales, originando con frecuencia inseguridades e insatisfacciones. De ahí que la ley optase por especificar que toda cuestión procesal que requiriese una decisión judicial había de ser resuelta por los tribunales, bien por medio de una providencia, bien a través de un auto, según los casos, en tanto que la ordenación formal y material del proceso, en definitiva, las resoluciones de impulso procesal, quedaban reservadas a los secretarios judiciales, indicando a lo largo del texto articulado en qué momentos debe dictarse una diligencia de ordenación a través del uso de formas impersonales, que permiten deducir que la actuación correspondiente deben realizarla aquéllos en su calidad de encargados de la correcta tramitación del proceso» (Informe del Pleno del CGPJ sobre el anteproyecto). 
Se busca una justicia más ágil, transparente y conforme a los valores constitucionales a través de una racionalización y optimización de los recursos que van destinados a la Administración de Justicia. Lo anterior exige separar con claridad los ámbitos de actuación de jueces y secretarios judiciales, cobrando un protagonismo en la reforma los integrantes de dicho cuerpo al potenciarse sus competencias sin menoscabo de la potestad jurisdiccional atribuida en exclusiva a jueces y tribunales. Así, le atribuyen funciones de impulso procesal colaterales a la función jurisdiccional tales como la admisión de la demanda, por ser una actuación reglada que no excluye que ante posibles errores estén sujetos al control de oficio que puede realizar el titular del órgano judicial en cualquier momento del procedimiento por vía de resolución de declinatoria ${ }^{5}$. Busca, por tanto, el legislador determinar con exactitud qué actos

En la misma línea citamos las palabras del portavoz del grupo parlamentario que sostenía al gobierno que presentó el proyecto en el seno de la Comisión legislativa del Congreso:

«Señorías, la reforma parte de la premisa de una nueva distribución de las funciones y cargas de trabajo en una moderna oficina judicial que implica necesariamente el reconocimiento de la figura del secretario judicial y la potenciación de sus competencias, sin menoscabo de la potestad jurisdiccional atribuida a jueces y tribunales, pero al mismo tiempo permitiendo al juez concentrarse única y exclusivamente en las funciones que le atribuye la Constitución, que no son otras que las de juzgar y hacer ejecutar lo juzgado. Por tanto, la idea inspiradora de la reforma ha sido la de concretar las competencias procesales del cuerpo de secretarios judiciales configurado como un cuerpo superior jurídico de modo que, salvo los supuestos en que una toma de decisión procesal pudiera afectar a la función estrictamente jurisdiccional, se ha optado por atribuir la competencia del trámite de que se trate al secretario judicial. En este sentido, se han atribuido nuevas normas de competencia a los secretarios en cuanto a la iniciación y a la terminación de los procedimientos, también la admisión de la demanda con carácter general, correspondiéndole el examen formal de la misma y la concurrencia de los presupuestos de jurisdicción y competencia [...]».

5 «[...] En lo relativo a la puesta en marcha del procedimiento, se le atribuye al secretario judicial competencia para admitir la demanda. El acto procesal de admisión de la demanda se configura como una actuación reglada que se establece como norma general dado que, como dispone el artículo 403.1 de la Lev 1/2000, de 7 de enero, de Enjuiciamiento Civil, 'Las demandas sólo se inadmitirán en los casos y por las causas expresamente previstas en esta ley'. Salvo casos especiales previstos en el propio artículo, la ley y sólo exige la comprobación de ciertos requisitos formales (la falta de presentación de poderes de representación procesal, la carencia de postulación o defensa obligatorias, la falta de presentación de documentos que fueren necesarios, la ausencia de indicación de la cuantía en la demanda, etc.) y el examen de la jurisdicción y competencia objetiva y territorial, lo que, en la mayoría de los supuestos no es 
corresponden al letrado como responsable último de la ordenación procesal de aquellos otros actos que, vinculados con el ejercicio de la potestad jurisdiccional, deben quedar en manos del titular del órgano jurisdiccional. En este sentido, trámites como admisión de la demanda, art. 403 de la Ley 1/2000, acumulación de acciones, terminación del procedimiento por desistimiento o satisfacción extraprocesal corresponden al letrado de la Administración de Justicia. Se trata de trámites reglados que en la mayoría de los supuestos están sujetos a una comprobación material sin excluir el control de oficio por parte del juez o tribunal. A modo de ejemplo, el CGPJ, que habla de finalidad ilustrativa o didáctica de la reforma, considera de cita inexcusable el art. 179.1, que sustituye la mención al «órgano jurisdiccional» por «secretario judicial» en la función de dar de oficio al proceso el curso que corresponda; o el art. 186, que le atribuye la dirección procesal y la policía de estrados en las vistas de asuntos de su exclusiva competencia.

Visto el objetivo de la reforma, el legislador, al establecer los mecanismos de revisión de las decisiones del letrado de la Administración de Justicia, valora la incidencia de sus funciones en la efectividad de la tutela judicial efectiva. Régimen de recursos que se ha visto afectado tras la STC 58/2016, de 17 de marzo, que declara inconstitucional el primer párrafo del art. 102. bis LJCA, de 13 de julio (en adelante LJCA), que impide el control judicial de los decretos dictados por los letrados de la Administración de Justicia al resolver el recurso de reposición interpuesto contra diligencias de ordenación o decretos no definitivos. Entiende el TC, como expondremos a continuación, que el nuevo sistema de recursos permite un sector de inmunidad jurisdiccional incompatible con el derecho fundamental a la tutela judicial efectiva y la

más que una mera comprobación materia si se tiene además en cuenta que los posibles errores en la apreciación de la jurisdicción y competencia por parte del secretario judicial pueden corregirse, como a se hacía antes, a través de la declinatoria interpuesta por el demandado y, en todo caso, por el control de oficio que en cualquier momento del procedimiento puede realizar el juez o tribunal en los términos establecidos en la ley, se trata de un trámite perfectamente asumible por el secretario judicial». Cuestión distinta es la inadmisión de la demanda al afectar al derecho de acceso a la justicia que forma parte de la tutela judicial efectiva y en consecuencia se sigue reservando a jueces y tribunales «en la medida en que supone cercenar un derecho constitucionalmente reconocido requiere o exige un pronunciamiento judicial que fundamente su limitación, pronunciamiento que debe quedar en el ámbito jurisdiccional de Jueces y Tribunales. Esto significa que, apreciada por el Secretario judicial la falta de alguno de los requisitos o presupuestos de la demanda, deberá dar cuenta al Juez para que este se pronuncie definitivamente sobre su admisión» (Exposición Motivos Ley 13/2009). 
reserva de jurisdicción a los jueces y tribunales integrantes del poder judicial. Sentencia que ya ha levantado alguna voz crítica, procedente en gran parte del cuerpo de letrados de la Administración de Justicia, que puede ver mermado el reciente protagonismo que el legislador les había concedido en su papel de impulsores del proceso judicial. Seoane Cacharron (2016) describe, de forma entendemos excesiva, la situación posterior a la sentencia como de proceso inquisitivo, habiéndose, a su juicio, expulsado a los letrados de la Administración de Justicia. Más moderado en su crítica podemos citar a Martín Contreras (2016), quien argumenta que el incidente debió resolverse en vía judicial, teniendo el TC argumentos suficientes para no admitir el recurso de amparo y, una vez admitido, derivó en un problema al que el TC parece dar una solución que parte primero del resultado para buscar después argumentos que puedan vestirlo. Considera el autor excesivo llegar a la inconstitucionalidad de un precepto y presenta como alternativa el tratamiento del silencio administrativo como ficción procesal que ha llevado a dejar sin efecto el plazo de interposición del contencioso en caso de silencio. Solución en vía judicial que también defiende Cremades López de Teruel (2016) a través del control que el titular del juzgado tiene en la fijación de los criterios para el señalamiento de vistas, sin que en el caso analizado conste en autos que pusiera objeción alguna. Situación que no justifica que, en aras de la tutela judicial efectiva, la solución venga de la mano de un tercer control por la vía del recurso de revisión. Visión crítica que pone sobre la mesa la pérdida de utilidad de un recurso de reposición al dejar el TC subsistente el recurso de revisión frente a cualquier diligencia de ordenación o decreto no definitivo y, en consecuencia, consideran que se perderían los beneficios de la distribución de competencias entre jueces y letrados de la Administración de Justicia (Aragonés Seijo, 2016: 67).

Resulta indiscutible que tras la sentencia del TC queda tocado el régimen de recursos previsto en la ley, art. 102 LJCA, respecto de las resoluciones procesales dictadas por los letrados de la Administración de Justicia, que pasamos a exponer como paso previo al análisis de la STC 58/2016, de 17 de marzo.

\section{RECURSOS CONTRA LAS RESOLUCIONES DE LOS LETRADOS DE LA ADMINISTRACIÓN DE JUSTICIA}

\section{RESOLUCIONES PROCESALES}

Consecuencia del reforzamiento de las competencias de impulso procesal que por ley corresponden a los letrados de la Administración de Justicia, se introducen cambios tanto en las resoluciones a dictar como en los recursos a interponer. Con el objeto de unificar la terminología y adaptarla a las 
nuevas competencias del letrado de la Administración de Justicia, se utiliza la expresión "resoluciones procesales», para englobar tanto las resoluciones judiciales — providencias, autos y sentencias - como las del letrado de la Administración de Justicia, que tras la Ley 13/2009 pueden dictar tres tipos de resoluciones: las diligencias de ordenación, los decretos y las diligencias de constancia, comunicación o ejecución. Las primeras tienen por objeto dar a los autos el curso que la ley establece. Por su parte, el decreto queda reservado para actos cualificados dentro de la tramitación del proceso, como puede ser la admisión a trámite de recurso (PA) o la admisión de la demanda (PO), que no la inadmisión, reservada a los tribunales su resolución por estar unido a la tutela judicial efectiva. También se reserva el decreto para poner término al procedimiento del que el secretario tuviera atribuida competencia exclusiva, o cuando fuera preciso o conveniente razonar lo resuelto. Por último, las diligencias de constancia, comunicación o ejecución tienen por objeto reflejar en autos hechos o actos con trascendencia procesal.

\section{RÉGIMEN GENERAL DE RECURSOS FRENTE A RESOLUCIONES PROCESALES DEL LETRADO DE LA ADMINISTRACIÓN DE JUSTICIA}

El legislador, Ley 13/2009, unifica la denominación de los recursos interpuestos contra providencias y autos no definitivos en las jurisdicciones civil, social y contenciosa, desapareciendo la referencia al recurso de súplica en las dos últimas, en favor del término «recurso de reposición», al tiempo que se unifica la regulación de los recursos devolutivos, atribuyendo competencias similares al letrado de la Administración de Justicia en la preparación e interposición de los mismos. Además, se ha incluido en los emplazamientos ante el órgano ad quem el apercibimiento de que, en caso de no realizarse en el plazo concedido, se declararán desiertos los recursos, por entender que se trató de una omisión del legislador anterior.

En ese camino que busca descargar a los jueces de funciones que no tienen carácter jurisdiccional, se han modificado las distintas leyes procesales estableciéndose un sistema de recursos contra las resoluciones del letrado de la Administración de Justicia, atendiendo tanto a la resolución procesal que se recurre, como al órgano que lo resuelve, es decir, el propio letrado que lo ha dictado o el titular del órgano judicial. La revisión de las resoluciones procesales procedentes del letrado de la Administración de Justicia, en el orden contencioso administrativo, viene de la mano de dos recursos regulados en el artículo 102 bis LJCA (introducido por el artículo decimocuarto, apartado cuarenta y cinco de la Ley 13/2009) con normas de tramitación básicamente similares, siendo debatida y resuelta por el TC la constitucionalidad de dicho precepto en la sentencia objeto del presente estudio. 
En definitiva, se contemplan en la ley dos tipos de recursos: reposición frente a actos de mero impulso y tramitación reservando el recurso de revisión para los que pongan fin al procedimiento o impidan su continuación:

a) Recurso de reposición contra las diligencias de ordenación y decretos no definitivos del letrado de la Administración de Justicia que dictó la resolución. A interponer en el plazo de cinco días y del cual, una vez admitido a trámite, se debe dar traslado a las demás partes por término común de tres días, a fin de que puedan impugnarlo si lo estiman conveniente. Recurso cuya resolución corresponde al letrado de la Administración de Justicia mediante decreto dentro del tercer día y salvo que ponga fin al procedimiento o impida su continuación (en cuyo caso cabe recurso directo de revisión) no cabe recurso alguno. En términos del precepto legal, el art. 102.bis dispone en su apartado 2:

Contra el decreto resolutivo de la reposición no se dará recurso alguno, sin perjuicio de reproducir la cuestión al recurrir, si fuera procedente, la resolución definitiva. Cabrá recurso directo de revisión contra los decretos por los que se ponga fin al procedimiento o impidan su continuación. Dicho recurso carecerá de efectos suspensivos sin que, en ningún caso, proceda actuar en sentido contrario a lo que se hubiese resuelto. Cabrá interponer igualmente recurso directo de revisión contra los decretos en aquellos casos en que expresamente se prevea.

La no admisión de recurso contra el decreto resolutivo de la reposición no cierra la posibilidad de reproducir la cuestión al recurrir la resolución definitiva del recurso contencioso administrativo, lo que lleva a plantear si concurre causa de inadmisibilidad del amparo por falta de agotamiento de la vía judicial, tal y como exige el art.44.1.a) de la Ley Orgánica del Tribunal Constitucional, 2/1979, de 3 de octubre (en adelante LOTC). Opción que es rechazada por el TC en la citada sentencia, que resuelve el amparo por considerar «inútil» recurrir contra la resolución definitiva cuando la dilación indebida que plantea el señalamiento de la vista debe resolverse necesariamente antes de la conclusión del proceso. Llama la atención la postura del TC si tenemos en cuenta, como veremos, el camino que ha tenido que seguir el interesado hasta el momento en que se resuelve sobre la vulneración del derecho fundamental.

b) Recurso directo de revisión. Por su parte, cabe recurso de revisión directo contra los decretos por los que se ponga fin al procedimiento o impidan su continuación, así como contra los decretos en aquellos casos en que expresamente se prevea. Siendo además recurrible en revisión el decreto de inadmisión del recurso de reposición que habrá de resolver el juzgado 
o tribunal, a diferencia del recurso de revisión donde no cabe recurso contra la inadmisión del recurso de revisión que corresponde mediante providencia al juzgado o tribunal. En otras palabras, si bien la admisión de ambos recursos se le atribuye al letrado de la Administración de Justicia a quien también corresponde la inadmisión del recurso de reposición mediante decreto recurrible en revisión, la inadmisión del recurso de revisión es competencia del juzgado o tribunal mediante providencia, sin que sea susceptible de recurso su decisión.

La tramitación de ambos recursos es similar. Se establece un plazo de cinco días para su interposición, si bien se amplía de tres a cinco días, en caso de revisión, en cuanto al plazo de alegaciones y resolución. Una vez admitido se da traslado a las partes para impugnarlo y en cuanto a los efectos del recurso se recoge de forma expresa que la interposición es en un solo efecto sin que suspenda la resolución recurrida. Por su parte, en cuanto al régimen de recursos contra el auto que resuelve el recurso de revisión y que corresponde al juzgado o tribunal, el apartado 4 del art. 102 bis dispone: «Contra el auto dictado resolviendo el recurso de revisión únicamente cabrá recurso de apelación y de casación en los supuestos previstos en los artículos 80 y 87 de esta Ley, respectivamente». La remisión genérica a dos preceptos de la LJCA, para concluir que son susceptibles de recurso en apelación o casación los autos que resuelven el recurso de revisión contra el decreto del letrado, limitado por tanto a aquellos supuestos en los que cabe recurso de revisión. Para Escribano Testaut (2013) el hecho de que se contemple la casación para impugnar unas resoluciones que confirman o corrigen un decreto del letrado de la Administración de Justicia, resulta indicativo de que las materias incluidas en el ámbito de los decretos son materias que realmente entran dentro del ámbito de la potestad jurisdiccional del juez o tribunal, y precisamente por ello reciben el tratamiento procesal que, a efectos de recurso, se da a las resoluciones directamente dictadas por estos. Si bien, como apunta con buen criterio Banacloche Palao (2016), al descender al caso concreto no es tan clara la delimitación entre resoluciones de carácter jurisdiccional y aquellas que no lo son.

\section{HECHOS DE LOS QUE TRAE CAUSA EL AMPARO}

Por resolución de la Delegación del Gobierno en Madrid de 22 de septiembre de 2010 se decreta la expulsión del territorio nacional de un ciudadano extranjero en situación de ilegalidad sin documentación que acredite su estancia legal en España, con prohibición de entrada en el país por un periodo de tres años y en los restantes territorios comprendidos en el Convenio de 
Aplicación del Acuerdo Schengen, de 19 de junio de 1990. Interpuesto recurso contencioso ante el Juzgado de lo Contencioso-Administrativo núm. 27 de Madrid, se incoa el Procedimiento Abreviado 30/2011. Ante una orden de expulsión el interés fundamental de quien recurre es permanecer en España. Resulta esencial, por ello, la adopción de la medida cautelar que suspenda la inmediata ejecución del acto administrativo, siendo acordada en este caso por auto de 26 de enero de 2011 que confirma la medida cautelarísima de suspensión de la orden administrativa, en tanto no se ponga fin al procedimiento de expulsión previamente acordada por el Juzgado de Instrucción núm. 14 de Madrid (en funciones de guardia). Suspensión que se mantiene hasta la Sentencia del Juzgado de lo Contencioso núm. 27 de Madrid, 203/2014, de 28 de abril, estimatoria del recurso contencioso y que anula y deja sin efecto la resolución impugnada de 22 de septiembre de $2010^{6}$.

En el curso de la tramitación procesal que contempla la LJCA 29/1998 (art.78) para los procedimientos abreviados, se acuerda por Decreto de 25 de abril de 2011 la admisión a trámite de la demanda y por diligencia de ordenación de la misma fecha del secretario del juzgado se convocó a las partes, conforme a lo dispuesto en el art. 182 LEC, el 22 de abril de 2014 para la celebración de vista oral. Con fecha 10 de mayo de 2011, la representación procesal del interesado interpuso recurso de reposición contra la diligencia de ordenación de 25 de abril de 2011. La alegación central de la parte actora en dicho recurso era denunciar que se superaba en exceso el plazo razonable para fijar el señalamiento de la vista, lo que vulneraba el derecho a un proceso sin dilaciones indebidas del art. 24.2 CE, y suplica, al amparo del art.63.1 LJCA, anticipar la fecha de celebración de la vista a un plazo razonable, con preferencia a otros procedimientos abreviados donde los demandantes arriesgan un menor interés. Recurso que fue desestimado por decreto del letrado de la Administración de Justicia de 26 de mayo de 2011, que confirma en todos sus extremos la diligencia recurrida, al entender que el señalamiento de la vista era conforme a derecho (art. 182 LEC y 78 y ss. LJCA) y, por tanto, sin acoger la alegación de entender, por lo dilatado del plazo de señalamiento para la vista tres años después, vulnerado el derecho a un proceso sin dilaciones indebidas.

6 Estimación que parte de la jurisprudencia del TS sobre la adopción de la medida de expulsión (como medida discrecional frente a la medida de multa) en caso de extranjeros en situación de ilegalidad y que exige que concurran elementos negativos que así lo justifiquen. Elementos negativos que no concurren en el expediente administrativo, pues la ausencia de elementos positivos no supone por sí misma un elemento negativo adicional a la estancia irregular sin que se puedan tener en consideración procedimientos sancionadores caducados. 
No siendo susceptible de recurso la resolución del recurso de reposición (art. 102 bis LJCA), se interpone recurso de amparo por vulneración de su derecho a un proceso sin dilaciones indebidas del art. 24.2 CE.

\section{RECURSO DE AMPARO ATÍPICO POR FALTA DE ACTO U OMISIÓN DE ÓRGANO JUDICIAL. ORIGEN «JUDICIAL» DE LA LESIÓN INVOCADA. ART.44.1.B) LOTC}

\section{OBJETO DE QUEJA EN AMPARO}

Objeto de tutela en amparo son los derechos y libertades fundamentales, recogidos en los arts.14 a $29 \mathrm{CE}$ y la objeción de conciencia del art. $30 \mathrm{CE}$. La tutela en amparo, pues, engloba tanto derechos fundamentales sustantivos como procesales gozando estos últimos, especialmente, la tutela judicial efectiva, de mayor relevancia en la jurisprudencia del TC. Y dentro de estos encontramos en el recurso de amparo contra actos u omisiones de órganos judiciales el supuesto más frecuente de amparo constitucional en tanto que la jurisdicción ordinaria debe garantizar y proteger los derechos fundamentales en el proceso, siendo imputable al órgano judicial la vulneración de los mismos. Para la admisión del amparo bajo la vía del art. 44 LOTC resulta indispensable que la violación del derecho o libertad sea imputable de modo inmediato y directo a una acción u omisión del órgano judicial ${ }^{7}$.

En el caso objeto de estudio, la queja formulada en amparo tiene como eje central la afección del derecho fundamental a un proceso sin dilaciones indebidas (art. $24 \mathrm{CE}$ ), al haberse señalado la vista, por diligencia de ordenación de 25 de abril de 2011 confirmada por decreto del letrado de la Administración de Justicia de 26 de mayo, para el 22 de abril de 2014, esto es, tres años después de la admisión a trámite de la demanda ante el Juzgado de lo Contencioso-Administrativo núm. 27 de Madrid (PA 30/2011). Calificado de remedio subsidiario el recurso de amparo, al que solo cabe acudir cuando se han agotado todas las posibilidades procesales para evitar la vulneración de

\footnotetext{
Como explica Carrillo (2008:101), la reforma del recurso de amparo tras la LO 6/2007 se centra en la objetivización del recurso de amparo a través del requisito de la trascendencia constitucional de objeto de la demanda y del juicio en positivo de admisión a trámite de la demanda. Valora el autor en sentido positivo el proceso de objetivización de la demanda de amparo sin que se dude de su constitucionalidad. Se confiere al recurso de amparo, en palabras de De la Oliva (2008:15), una nueva esencia: la de ser instrumento de interpretación de la CE declarando el sentido que el TC quiere dar a determinados preceptos de la Norma Fundamental.
} 
un derecho fundamental, sin perjuicio de la protección a dispensar por los tribunales (Rubio Llorente 1982:65), exige que siempre vaya precedido de una acción ante los órganos del Poder Judicial, siendo objeto de impugnación en el recurso constitucional una decisión judicial previa que, como apunta el autor, o bien no ha remediado la lesión de un derecho fundamental imputable a la actuación de otro poder público o bien lo ha lesionado directamente. En el caso que nos ocupa, si el acto que a criterio de quien demanda en amparo lesiona un derecho fundamental, procede del secretario judicial y no del titular del juzgado y, como decimos, la lesión constitucional recurrible en amparo solo puede ser atribuible a una actuación de los órganos judiciales, nos encontramos ante una situación que la Sala $2^{\text {a }}$ del TC, en el auto de 9 de septiembre de 2013, califica de atípica y problemática en cuanto a su encaje en el art. 44 LOTC.

Sin entrar en el debate descrito, la demanda fue admitida a trámite por providencia de 15 de marzo de 2012 y a tenor de lo dispuesto en el art. 52.1 LOTC, por diligencia de ordenación de 12 de abril de 2012, se acordó dar vista de las actuaciones por plazo común de veinte días a las partes para formular las alegaciones que a su derecho convinieran en el Recurso de Amparo 4577/2011. Alegaciones que ponen de manifiesto la discrepancia jurídica entre la abogacía del Estado, que defiende la legalidad de la norma, solicita la inadmisión del amparo por defectos procesales y subsidiariamente la desestimación de la demanda, y el Ministerio Fiscal, que se manifiesta claramente a favor del otorgamiento al amparo solicitado, al entender vulnerado el derecho fundamental a un proceso sin dilaciones indebidas ${ }^{8}$.

En su escrito de alegaciones, el abogado del Estado interesa la inadmisión del amparo al no justificar la parte recurrente la especial trascendencia constitucional del recurso sin que se haya aportado principio de prueba que acredite un incumplimiento generalizado en el señalamiento de vistas en los procedimientos contenciosos abreviados sobre sanciones de expulsión. Subsidiariamente, para el caso de no estimar la sección del tribunal que corresponda la concurrencia de la causa de inadmisión, solicita la denegación del amparo. Entiende que el interés fundamental del extranjero de permanecer

8 Se reiteran las posturas enfrentadas entre la abogacía del Estado y el Ministerio Fiscal ante el TC que ya es común en los procedimientos constitucionales de amparo por dilaciones indebidas, consecuencia del retraso en el señalamiento de la vista dentro del procedimiento contencioso abreviado que tienen por objeto una orden de expulsión de extranjeros en situación de ilegalidad (STC 141/2010, de 21 de diciembre; STC 99/2014, de 23 de junio; STC 89/2014, de 9 de junio; STC74/2015, de 27 de abril y STC $87 / 2015$, de 11 de mayo). 
en España queda protegido por la resolución cautelar al haberse suspendido la orden de expulsión en tanto esté abierta la vía judicial, siendo meramente hipotéticos los daños que pudieran derivarse del retraso en el señalamiento de la vista. A lo anterior se une que la duración del procedimiento abreviado está dentro del margen ordinario de duración de los litigios del mismo tipo y califica de «escasamente realista calificar de deficiencias estructurales generadoras de dilaciones indebidas que merecen ser amparadas aquellas que resulten de comparar la realidad empírica de un sistema judicial con una especie de ideal de funcionamiento, que tampoco es seguro que se alcanzara por mucho que se incrementara la inversión en la organización judicial, algo por lo demás impensable en el actual contexto de aguda y profunda crisis financiera pública». La petición de restablecimiento del derecho a un proceso sin dilaciones indebidas que se recoge en la demanda de amparo «obligando al juzgado de instancia a anticipar el señalamiento para la celebración de la vista en el procedimiento abreviado 30/2011» debe ser desestimada al ser doctrina constitucional que el derecho a un proceso sin dilaciones indebidas busca asegurar que la atención se preste en términos usuales o normales, atendiendo al tipo de asunto que puede o no coincidir con las expectativas que se puedan abrigar (STC 94/2008, de 21 de julio, FJ3).

Criterio distinto se recoge en el escrito de alegaciones presentado por el Ministerio Fiscal, que interesa el otorgamiento parcial del amparo al defender la vulneración, a resultas de causas estructurales de la organización judicial, del derecho a un proceso sin dilaciones indebidas (siendo los 36 meses un periodo muy superior a los 17-19 meses que el TC consideró excesivos en SSTTC 93/2008 y 141/2010), pero de otra parte no consta que el órgano judicial obrase con falta de diligencia al señalar la vista con respeto escrupuloso del orden cronológico de señalamientos. Discrepa de la abogacía del Estado en la valoración del interés que en el proceso arriesga el demandante que califica de esencial o especialmente relevante no solo para sus derechos e intereses legítimos que afectan tanto a la vida privada y familiar como al interés de un menor de nacionalidad española.

A la vista de las alegaciones formuladas por las partes, nos llama la atención que nada dicen en este momento procesal sobre la no concurrencia de los requisitos de admisión del recurso de amparo dado el papel subsidiario que corresponde al TC respecto de la tutela de la jurisdicción ordinaria al ser objeto de amparo una decisión del letrado de la Administración de Justicia. Pero la realidad es que dicha cuestión procesal de admisibilidad está presente; es más, si el Pleno del TC hubiera declarado la constitucionalidad de la norma, la Sala $2^{a}$ del TC tendría nuevamente sobre la mesa un recurso de amparo sin acción u omisión judicial. Pero en el momento en que la norma, art. 102 bis, es excluida del ordenamiento jurídico por inconstitucional, pierde fuerza el debate 
de admisión del amparo por no concurrir un acto de órgano judicial que la propia norma inconstitucional impedía. No obstante, la inconstitucionalidad del precepto citado entendemos que resulta un punto clave que no podemos obviar, pues deriva en un círculo cerrado al que hay que buscar una salida. Se plantea un supuesto donde, de una parte, se impide al interesado la revisión judicial de la decisión que procede del 74/2015, de 27 de abril, pues la propia norma procesal, art. 102 LJCA, excluye la revisión de la decisión por el titular del juzgado y, en consecuencia, no hay acto judicial, y de otra, se bloquea el acceso al amparo como último recurso para la tutela de un derecho que corresponde a los órganos judiciales, pero que, sin embargo, no se contempla.

\section{2. ¿̇SERÍA ADMISIBLE UNA INTERPRETACIÓN AMPLIA DEL «ÓRGANO JUDICIAL» INTEGRANDO LAS RESOLUCIONES DE QUIEN NO ES EL JUEZ O TRIBUNAL? ¿̇QUÉ ACTOS SON ACTOS JUDICIALES?}

Siguiendo a García Murcia (2001:704), para determinar qué lesiones han sido causadas por un órgano judicial resulta decisiva la naturaleza jurídica del acto lesivo teniendo en cuenta la configuración jurídica y la función atribuida al órgano correspondiente. En palabras del autor, «sólo podrá hablarse de acto judicial cuando proceda de un órgano adscrito a la organización judicial del Estado y dedicado a la solución de conflictos y litigios por métodos jurisdiccionales. El artículo 44 se refiere, sin duda, a los actos que, de acuerdo con el artículo $117 \mathrm{CE}$, tienen potestad jurisdiccional para juzgar y hacer ejecutar lo juzgado, conforme a lo determinado por la LOPJ 6/1985 (arts. 2 y ss) y Ley 38/1988». Concepto restrictivo que limita el art. 44 a aquellos actos que provengan de los juzgados y tribunales determinados en las leyes, dejando fuera del ámbito de acción de dicho preceptos los actos que tienen naturaleza pública pero no judicial: actos de origen parlamentario; actos que proceden de órganos consultivos del Estado como el Consejo de Estado; actos administrativos que tienen su propia vía de impugnación del art. 43 LOTC atendiendo al origen administrativo de la lesión sin que altere su naturaleza no jurisdiccional la posterior intervención judicial al ser siempre necesario el agotamiento de la vía judicial que proceda, sin perjuicio de una doble lesión administrativa y judicial que nos lleva a un recurso de amparo de carácter mixto. En consecuencia, como pone de manifiesto Fernández Farreres (1994:160), no deberían imputarse a los órganos judiciales que confirman el acto administrativo la lesión del derecho fundamental, sin que el requisito de agotamiento de la vía judicial previa pueda transformar al amparo frente a resoluciones del Poder Ejecutivo (art. 43) en amparo frente a resoluciones judiciales (art. 44). A los anteriores actos, García Murcia (2001:704) añade los actos de resolución de conflictos fuera del Poder Judicial como pueden ser las decisiones de 
órganos de conciliación, mediación o arbitraje. Así como actos de órganos que revisten, sin integrar el Poder Judicial, la forma de tribunal como el Tribunal de Cuentas o, por citar alguno más, el Tribunal Administrativo Central de Recursos Contractuales. Sin perjuicio de que dichas decisiones si son impugnadas dejan abierta la vía del art. 44.

Este presupuesto de acto judicial exige, en definitiva, una acción u omisión de un órgano judicial pues solo es recurrible en amparo un acto de naturaleza genuinamente judicial que provenga de un juzgado o tribunal integrado en el Poder judicial en el ejercicio de jurisdicción. A modo de ejemplo, podemos citar que no puede el TC valorar la intervención del letrado o del representante procesal en las causas judiciales. Por todas, ATC 216/1988, de 15 de febrero, que ante un escrito de demanda y alegaciones del recurrente se deduce que la indefensión que dice haber sufrido tiene su origen en la actuación del abogado que le defendió durante el proceso penal, no en un acto u omisión de la Audiencia Provincial o del TS a quien no puede imputárseles los defectos habidos en el ejercicio de la postulación procesal, ni considerárseles responsables de los mismos, pues no les corresponde a ellos dirigir la defensa de una de las partes del proceso, por ser incompatible con la imparcialidad que su función de jueces requiere. De la misma manera, no son amparables constitucionalmente las lesiones de derechos fundamentales resultantes de la relación entre el justiciable y el procurador, sin perjuicio de las acciones que le correspondan por otra vía consecuencia del perjuicio que se le haya podido ocasionar por la dejación de las obligaciones profesionales que le corresponden como representante procesal, como puede ser la no comunicación a su cliente de un auto que le fue notificado (ATC 348/1991, de 25 de noviembre). Tampoco es un acto u omisión de un órgano judicial el que procede del Ministerio Fiscal (ATC 219/84, de 4 de abril).

La premisa de partida que apuntaba García Murcia (2001:704) de atender a la naturaleza jurídica del acto lesivo y la función atribuida al órgano correspondiente, nos lleva a excluir los actos no jurisdiccionales de los jueces y tribunales, tales como los actos registrales que se han atribuido los órganos judiciales por razones que ahora es innecesario exponer y que tal y como afirma el TC no convierten automáticamente aquella función en jurisdiccional. ${ }^{9}$ Quedan fuera también los actos gubernativos de los tribunales que,

9 El Registro Civil, pese a estar encomendada su llevanza a órganos judiciales, no es función jurisdiccional, sino registral. Así lo recoge el TC, en STC 56/1990, de 29 de marzo, donde afirma que: «El Registro Civil, pese a estar encomendada su llevanza a órganos judiciales, no es función jurisdiccional, sino registral. Así expresamente se deduce del art. 2 de la LOPJ que, tras precisar en su apartado $1 .^{\circ}$ que el ejercicio de 
dado su carácter administrativo, no actúan como verdadero órgano judicial (STC 3/1982, de 8 de febrero) o aquellos que resulten de procedimientos de mediación, arbitraje o conciliación, como un equivalente jurisdiccional (STC $288 / 1993$, de 4 de octubre $)^{10}$. Lo anterior no excluye, como apunta Ulloa Rubio (2010:509), su posible impugnación ante el orden contencioso, previo agotamiento de la vía administrativa, que deja abierta la vía judicial.

Sí encuentran encaje en el art.44 LOTC aquellas lesiones que en su origen son imputables a la actuación de quien no tiene la condición de ente público, como un acto del Consejo de Administración de la Caja de Ahorros de Asturias, pero que no fueron reparados por el órgano judicial (STC 18/1984, de 7 de febrero). Fernández Farreres (1994:160) se posiciona claramente en sentido crítico hacia la interpretación amplia del concepto de poder público por parte del TC al permitir acudir en amparo frente a actos de particulares. El autor es crítico con la interpretación amplia por parte de la jurisprudencia constitucional del requisito de origen inmediato y directo de la lesión en una acción u omisión de órgano judicial como poder público que es «y que ha venido a desdibujarlo, y todo ello a fin de facilitar que puedan acogerse al amparo constitucional supuestos que, en otro caso, por estar referidos a presuntas lesiones de derechos fundamentales distintos de los garantizados por el art.24 CE y no ser imputables a ningún poder público, en forma alguna podrían haber accedido al amparo». Interpretación que ha permitido el acceso al amparo procediendo la lesión de acciones de particulares admitiendo el amparo sin plantearse si eran procesalmente viables

a través de la consideración de que la intervención del Juez, en la medida en que es un órgano del poder público <transforma> el conflicto entre particulares en un conflicto entre éstos y un poder público...artificio o ficción de imputar al órgano judicial la vulneración del derecho fundamental que trae causa de la actuación de simples particulares. Una interpretación del requisito de que la vulneración tenga

la potestad jurisdiccional corresponde a los juzgados y tribunales, en el $2 .^{\circ}$ puntualiza que éstos, además de la función jurisdiccional, no podrán ejercer más funciones que las del Registro Civil y las demás que expresamente les atribuya la ley en garantía de cualquier derecho. Los jueces a los que, además del ejercicio de la correspondiente función jurisdiccional, se les encomienda la llevanza del Registro Civil, en esta función no actúan como órganos jurisdiccionales, sino como registradores o encargados del Registro».

10 Por el contrario, sí se considera acto de naturaleza judicial el auto que procede de la Sala de Gobierno de la desaparecida Audiencia Territorial al excluir el TC que estemos ante actos imputables a un órgano gubernativo de carácter administrativo (STC 288/1993, de 4 de octubre). 
un origen directo e inmediato en un acto u omisión judicial tan amplia y expansiva que prácticamente lo hace superfluo.

\section{RECURSO DE AMPARO ATÍPICO NÚM. 4577-2011 CONTRA LA DILIGENCIA DE ORDENACIÓN DEL LETRADO DE LA ADMINISTRACIÓN DE JUSTICIA QUE CONVOCÓ A LAS PARTES PARA LA CELEBRACIÓN DE LA VISTA DEL PA 30-2011}

La interpretación constitucional del concepto de acto judicial, descrita en el punto anterior, resulta clave en el resultado de la admisión del amparo promovido por el interesado. Si tenemos en cuenta que los medios de impugnación que contempla la norma procesal contenciosa fijan el techo de revisión, vía recurso de reposición, en el letrado de la Administración de Justicia que ha dictado la resolución lesiva para el derecho fundamental, sin admitir la revisión por el titular del juzgado surge la cuestión de la admisibilidad de un recurso en amparo frente a una resolución con posible vulneración de un derecho fundamental no revisable por el titular del Juzgado de lo Contencioso núm. 27 de Madrid.

El Ministerio Fiscal ante el TC en nuevo escrito de alegaciones, de 11 de septiembre de 2012, excluye, consecuencia de la naturaleza subsidiaria del recurso de amparo, una interpretación amplia del art. 44.1 LOTC que comprenda también las decisiones no jurisdiccionales adoptadas por el letrado de la Administración de Justicia. Para el Ministerio Público la atribución a los jueces y tribunales de la guardia natural y primera de los derechos fundamentales exige que la lesión de los mismos como objeto de amparo sea imputable a los actos y omisiones del órgano judicial en sentido específico, referido al juez o tribunal y no en sentido amplio que comprenda los actos y decisiones que provengan del personal al servicio de la Administración de Justicia que integra la oficina del órgano judicial a cuyo frente se encuentran los secretarios judiciales, hoy letrados de la Administración de Justicia. Argumento que entendemos se ajusta al modelo de oficina judicial donde, como apuntamos al principio del presente trabajo, a la hora de distribuir las competencias el legislador deja claro que en ningún caso el letrado de la Administración de Justicia es titular de la potestad jurisdiccional que corresponde en exclusiva a los jueces y tribunales.

Por otro camino discurre la argumentación de la abogacía del Estado ante el TC que descarta que estemos ante un supuesto atípico donde no exista una resolución del titular del órgano judicial sobre la actividad judicial que permita evaluar una posible vulneración de un derecho fundamental. Para la representación del Estado estamos ante un caso donde no se ha agotado la vía 
judicial, tal y como exige el art. 44.1.a) LOTC. Entiende que el interesado debió esperar a la resolución definitiva del proceso y entonces someter a revisión jurisdiccional la decisión del letrado de la Administración de Justicia en el recurso contra la resolución definitiva del proceso. En consecuencia, concurre otra causa de inadmisibilidad: la falta de agotamiento de la vía judicial previa que exige el art. 44.1.a) LOTC. En caso de haber sometido a revisión jurisdiccional en el recurso contra la resolución definitiva el resultado hubiera sido distinto, pues de una parte hubiera permitido al titular del juzgado pronunciarse sobre la fijación de la vista y de otra, en caso de pronunciarse en sentido contrario a los intereses del recurrente y entender este que se ha conculcado un derecho fundamental tendría, ahora sí, un acto judicial susceptible de amparo.

El propio Pleno del TC (STC 58/2016, de 17 de marzo, FJ. 6), al plantear alternativas al sistema de recursos excluye el incidente de nulidad por no provenir del juez o tribunal la vulneración del derecho garantizado por el art. 24.2 CE. Por su parte, la Sala 2a TC, en cuanto al carácter atípico del recurso, a pesar de que antes afirmaba que no cabe una interpretación amplia de la expresión "acto u omisión de un órgano judicial» del art. 44 LOTC que permita, en palabras del Tribunal, convertir en objeto del recurso de amparo todo acto procedente de cualquier sujeto que se encuentre incluido en la organización judicial, no excluye ahora tal posibilidad en STC 208/2015, de 5 de octubre, si bien bajo la expresión «nos vimos obligados a examinar sendas resoluciones procesales de un Secretario Judicial que, extralimitándose en su competencia, negó a la parte demandante de amparo en aquel asunto la condición de parte en el procedimiento judicial a quo». Términos que parecen apuntar que estamos ante supuestos excepcionales sin que resulte admisible una interpretación amplia que venga a alterar el régimen establecido.

Llegados a este punto, el TC supera la sorpresa, término ilustrativo empleado por Banacloche Palao (2016), o la situación incómoda a que hace referencia González Casso (2016) de tener que resolver un recurso de amparo frente a un decreto del letrado de la Administración de Justicia y traslada el debate del ámbito subjetivo de lesión de un derecho fundamental al objetivo de nulidad de una norma. Como hemos visto, el TC se inclina hacia una interpretación contraria al examen, vía amparo, de resoluciones del letrado de la Administración de Justicia, pero con una finalidad garantista no quiere dejar desprotegido al interesado y para ello utiliza el mecanismo de objetivar el recurso de amparo por el camino que contempla el art. 55.2 LOTC. No existe acto procedente del titular del juzgado por cuanto el art. 102 bis.2 LJCA lo excluye y es por ello que, ante el posible perjuicio a un derecho fundamental, considera procedente elevar al Pleno cuestión de inconstitucionalidad respecto del citado precepto que excluye la revisión del decreto 
que resuelve el recurso de reposición contra diligencias de ordenación del secretario del Juzgado. Entiende la Sala $2^{\text {a }}$ que se dan los presupuestos del art. 55.2 LOTC: cuando el recurso de amparo debiera ser estimado porque a juicio de la Sala, la ley aplicable (art. 102 bis, apartado 2 LJCA) lesione derechos fundamentales (derecho a un proceso sin dilaciones indebidas) se elevará una cuestión interna de inconstitucionalidad al Pleno con suspensión del plazo para dictar sentencia ${ }^{11}$.

\section{CUESTIÓN INTERNA DE INCONSTITUCIONALIDAD}

Los escritos de las partes de alegaciones sobre la pertinencia de plantear la cuestión de inconstitucionalidad evidencian posturas enfrentadas. De una parte la abogacía del Estado refleja en sus alegaciones una oposición rotunda y vehemente al planteamiento de una cuestión que llevaría a la creación de un recurso excepcional que el legislador no ha previsto ni querido prever. No estamos ante la eliminación de una norma inconstitucional, sino a la imposición, vía sentencia, de un recurso ex novo de revisión, siendo dudoso que la norma suprema haya atribuido tal competencia al TC. Criterio distinto mantiene el fiscal informante para quien concurren motivos suficientes para avalar la conveniencia de elevar la cuestión al Pleno en un caso como el que nos ocupa, donde se priva al justiciable de revisión judicial de una resolución procesal que pueda vulnerar un derecho fundamental.

11 Una de las novedades de la reforma operada por la LO 6/2007, de 24 de mayo, de la LOTC, fue la previsión de elevar por la Sala al Pleno una cuestión de inconstitucionalidad antes, y no después de resolver una demanda de amparo, con suspensión del plazo para dictar sentencia en el recurso de amparo. Así lo contempla el art. 55.2 LOTC, con remisión a los arts. 35 y ss., que regulan la cuestión de inconstitucionalidad promovida por jueces o tribunales, cuando la lesión de derechos tenga causa, origen en la norma legal aplicada por la resolución judicial en amparo. El auto de la Sala Segunda de 9 de septiembre de 2013, de planteamiento de la cuestión interna de inconstitucionalidad, supera la simple descripción que caracterizaba a los autos anteriores a la reforma y fundamenta el cuestionamiento de la ley aplicable. Para Requejo Pagés et al. (2009: 228) cabe preguntarse si el nuevo sistema no implica la obligación por parte de la Sala de fundamentar el cuestionamiento de la ley que antes estaba implícita en los razonamientos que llevaban a estimar el amparo. En palabras del autor «faltando la fundamentación supone privar al Pleno de todo elemento de juicio y poner públicamente en duda la legitimidad de una ley sin otro fundamento que el argumento de autoridad». 
Lo anterior no excluye que, ante la situación atípica descrita, se busquen instrumentos o alternativas legales al régimen de recursos, a una situación que puede convertirse en un círculo cerrado, un callejón sin salida, al no ser compatible la naturaleza subsidiaria del amparo constitucional con una interpretación amplia del art. 44 LOTC que permita incluir dentro de los actos y omisiones del órgano judicial aquellos que sean adoptados por el personal al servicio de la Administración de Justicia que integra la Oficina Judicial, a cuyo frente se sitúan los letrados de la Administración de Justicia:

a) ante la falta de previsión legal, bajo una interpretación teleológica y sistemática, el Ministerio Fiscal defiende la subsistencia de un recurso de revisión judicial cuando se plantea la posible vulneración de un derecho fundamental cuyo examen participa de la naturaleza de potestad jurisdiccional y por ello no concurren los presupuestos legales para que sobre dicha denuncia conozca y resuelva el letrado de la Administración de Justicia. Lo cierto es que la reforma procesal, como hemos apuntado anteriormente, ha atribuido a los letrados de la Administración de Justicia, más allá del impulso procesal del procedimiento, competencia tradicional, funciones indispensables y decisorias en materias colaterales a la propiamente jurisdiccional. $Y$ en ese nuevo reparto de competencias no podemos dejar nunca de tener presente dicho límite; es por ello que, al establecer el régimen general de recursos, sólo sería admisible el recurso de revisión cuando la decisión pueda afectar a un derecho fundamental por ser materia que corresponde conocer al titular del juzgado. Razonamiento lógico que entendemos no excluye que, ante la falta de previsión por el legislador de revisión por el titular del juzgado, la abogacía del Estado pueda plantear la inadmisión del mismo, pues los recursos son los que son y no lo que queremos que sean en su interpretación. Pero sí es cierto que no resulta admisible dar al secretario judicial una competencia para conocer de un recurso que claramente entra dentro del campo de la potestad jurisdiccional por afectar a un derecho fundamental. Siendo en este punto ajustado a derecho el camino tomado por la Sala $2^{a}$ de plantear una cuestión interna de inconstitucionalidad respecto de una norma como es el art. 102 LJCA, que veda la intervención del titular del órgano ante un debate claramente jurisdiccional. Lo que no es óbice para valorar, desde un punto de vista crítico, que el resultado de la sentencia va más allá al extender la revisión a toda decisión del letrado de la Administración de Justicia y no solo a aquellas que puedan afectar a un derecho fundamental. 
b) La posible alternativa de promover un incidente de nulidad de actuaciones, art. $241.1 \mathrm{LOPJ}^{12}$, tampoco puede prosperar al haber sido ya invocada, denunciada y sometida a examen vía recurso de reposición la lesión del derecho fundamental. Sin que pueda imputarse al recurrente la falta de cumplimiento del requisito previsto en el art. 44.1.a) LOTC, de agotamiento de los medios de impugnación al haber denunciado la lesión del derecho vía recurso de reposición que es legalmente previsto contra diligencias de ordenación (art. 102 LJCA).

c) Nos queda el camino que deja abierto el art. 102 bis.2 de reproducir la cuestión al recurrir, si fuera procedente, la resolución definitiva y que permite la revisión jurisdiccional de eventuales vulneraciones de derechos fundamentales que provengan de diligencias de ordenación en el recurso que en su día se interponga contra la resolución definitiva del proceso y una vez se agote esta vía de recurso quedará abierto el camino del recurso de amparo. $\mathrm{Y}$ es entonces, en ese recurso de amparo, cuando se podrá alegar la vulneración del derecho a un proceso sin dilaciones indebidas que no fue corregida por el órgano judicial al resolver el recurso contra la resolución definitiva del proceso, concurriendo entonces una acción u omisión del órgano judicial, superando el debate de la admisión del amparo frente a decisiones que provienen del letrado de la Administración de Justicia. Opción que rechaza el Pleno al obviar que sólo podría reproducirse la cuestión cuando la resolución definitiva del proceso contencioso sea susceptible de recurso. Formulación general por parte del TC, propia del control abstracto de constitucionalidad de la norma, pero que no impide tener en cuenta que en el caso que nos ocupa, al ser

12 Como tiene declarado el TC, por todas auto de la Sala Segunda 9/2009, de 26 de enero: "Es doctrina reiterada de este Tribunal desde sus comienzos, por un lado, 'que no resulta acorde con el derecho a la tutela judicial el desarrollo de procedimiento judicial inaudita parte, más que en el caso de incomparecencia por voluntad expresa o tácita, o por negligencia imputable a la parte que pretende hacer valer ese derecho fundamental' ( SSTC 112/1987 [ RTC 1987, 112], 251/1987 [ RTC 1987, 251] ); y por otro, que no toda infracción o irregularidad procesal cometida por los órganos judiciales provoca, en todos los casos, la eliminación o discriminación sustancial de los derechos que corresponden a las partes en el proceso ( SSTC 35/1989 [ RTC 1989, 35], 52/1989 [ RTC 1989, 52], 145/1990 [ RTC 1990, 145], 61/1992 [ RTC 1992, $61]$ ), sino que se requiere la producción de una merma en sus posibilidades de defensa material». Merma de defensa que no ha concurrido en el caso objeto de estudio al haberse denunciado vía recurso de reposición la vulneración del derecho fundamental sin que concurran los requisitos que el art. 241.1 LOPJ establece para que pueda plantearse el incidente de nulidad de actuaciones. 
materia de extranjería y de cuantía indeterminada la sentencia que puso fin al contencioso, era susceptible de recurso de apelación ante la Sala de lo Contencioso-Administrativo del TSJ de Madrid, lo que de inicio podría plantear la no concurrencia de todos los requisitos de admisión del recurso de amparo por no agotarse todas las vías de impugnación que prevé la norma procesal, la LJCA, si bien hay que tener presente que no resulta exigible el presupuesto de agotamiento previo, cuando el derecho que se dice vulnerado es el derecho a un proceso sin dilaciones indebidas que debe ser alegado cuando el proceso judicial está pendiente para poder poner fin a la dilación denunciada. A lo anterior se suma que aún en el caso de ser susceptible de recurso la resolución definitiva, no se resolvería la duda de la constitucionalidad de la norma al afectar al régimen de protección del derecho fundamental a un proceso sin dilaciones indebidas que exige que el proceso judicial no haya finalizado ${ }^{13}$.

13 «En efecto, a diferencia de que lo sucede con los restantes derechos fundamentales tutelables en amparo (art. 53.2 CE [RCL 1978, 2836] y art. 41.1 LOTC [RCL 1979, 2383] ), que exigen el agotamiento de la vía judicial procedente como requisito inexcusable para poder acudir al recurso de amparo constitucional [arts. 43.1 y 44.1.a) LOTC (RCL 1979, 2383) ], y sin perjuicio de otras excepciones a la regla general de subsidiariedad (por todas, STC 4/2010, de 17 de marzo [RTC 2010, 4], FFJJ 3 y 4), en el caso del derecho a un proceso sin dilaciones indebidas la denuncia de la vulneración ha de efectuarse mientras el proceso judicial está aún pendiente, con el fin precisamente de poner fin a la dilación denunciada, puesto que de lo que se trata es de conseguir que el órgano judicial dicte la resolución que proceda sin más demora. De este modo, si las supuestas dilaciones no subsisten en el momento de interponerse el recurso de amparo entonces esta queja pierde su objeto, toda vez que la alegación de la lesión del derecho fundamental a un proceso sin dilaciones indebidas carece de sentido cuando el procedimiento ya ha finalizado - (entre otras muchas, SSTC 51/1985, de 10 de abril [RTC 1985, 51], FJ 4; 146/2000, de 29 de mayo [RTC 2000, 146], FJ 3; 237/2001, de 18 de diciembre [RTC 2001, 237], FJ 3; 73/2004, de 22 de abril [RTC 2004, 73], FJ 2; y 126/2011, de 18 de julio [RTC 2011, 126], FJ 5); la apreciación en el proceso constitucional de amparo de las pretendidas dilaciones indebidas no podría conducir a que este Tribunal adoptase medida alguna para hacerlas cesar- ( SSTC 224/1991, de 25 de noviembre [RTC 1991, 224], FJ 2; 97/2003, de 2 de junio [RTC 2003, 97], FJ 4; y 147/2006, de 8 de mayo [RTC 2006, 147], FJ único, por todas). En consecuencia, la tesis del Abogado del Estado no puede ser compartida, pues obligar al justiciable a esperar a que recaiga la sentencia resolutoria del proceso contencioso-administrativo para plantear en vía de recurso (cuando este proceda, no se olvide) la eventual vulneración del derecho fundamental al proceso sin dilaciones indebidas (art. 24.2 CE [RCL 1978, 2836]) vaciaría de contenido la tutela que el Tribunal Constitucional puede otorgar en relación con este derecho fundamen- 
Descartados los caminos descritos, la Sala 2a del TC, por auto de 9 de septiembre de 2013, acuerda elevar al Pleno del Tribunal cuestión interna de inconstitucionalidad respecto del art. 102 bis, apartado 2 LJCA. En el auto, la Sala $2^{\text {a }}$ califica la situación descrita como atípica y problemática, en cuanto a su encaje en el amparo contra actos judiciales a que se refiere el art. 44 LOTC, al emanar el acto que vulnera el derecho fundamental a un proceso sin dilaciones indebidas del letrado de la Administración de Justicia «sin que quepa realizar una interpretación amplia de ese concepto que permita convertir en objeto del recurso de amparo todo acto procedente de cualquier sujeto que se encuentra incluido en la organización judicial». Pero en la medida en que el art. 102 bis. 2 LJCA excluye del recurso directo de revisión el decreto resolutivo del recurso de reposición y priva al justiciable de someter la decisión última al titular del juzgado en un asunto que afecta a un derecho fundamental, el derecho a un proceso sin dilaciones indebidas que puede haberse visto afectado al señalar el día para la celebración de la vista a tres años, puede suponer una desatención a la tutela judicial efectiva del art. 24.1 CE y en consecuencia, en aplicación del art. 55.2 LOTC, acuerda elevar al Pleno cuestión interna de inconstitucionalidad que es estimada por Sentencia del Pleno del TC 58/ 2016 de 17 de marzo.

La duda de constitucionalidad recae sobre un precepto, el art. 102 bis, que deja abierto un sector de inmunidad jurisdiccional ante supuestos, como el caso que nos ocupa, donde la decisión del letrado de la Administración de Justicia queda «excluida por el legislador del recurso de revisión ante el juez o tribunal concierna a cuestiones relevantes en el marco del proceso, que atañen a la función jurisdiccional reservada en exclusiva a jueces y magistrados». $\mathrm{Al}$ privar al justiciable de la revisión por el titular del órgano judicial de una cuestión que afecta a un derecho fundamental como es el derecho al proceso sin dilaciones indebidas, se puede producir una desatención del derecho a la tutela judicial efectiva. Esta tutela debe ser dispensada por quienes son en exclusiva titulares del ejercicio de la potestad jurisdiccional, los jueces y tribunales, lo que veda que el legislador excluya de manera absoluta la posibilidad de recurso contra los decretos de los letrados de la Administración de Justicia resolutorios del recurso de reposición. En suma, el párrafo primero del art. 102 bis. 2 incurre en insalvable inconstitucionalidad al crear un espacio de

tal. Pues, de acuerdo con la doctrina citada, carece de objeto alegar la vulneración del derecho a un proceso sin dilaciones indebidas cuando estas, de haberse efectivamente producido, ya han cesado, al haber finalizado el proceso judicial. No resulta posible, por tanto, la interpretación secundum constitutionem del precepto legal cuestionado que propone la abogacía del Estado» (STC 58/2016, de 17 de marzo). 
inmunidad jurisdiccional incompatible con el derecho fundamental a la tutela judicial efectiva y la reserva de jurisdicción a los jueces y tribunales integrantes del poder judicial. El precepto cuestionado, en cuanto excluye del recurso judicial a determinados decretos definitivos del letrado de la Administración de Justicia (aquellos que resuelven la reposición), cercena, como señala el ATC 163/2013 (PROV 2013, 338069), FJ2, el derecho del justiciable a someter a la decisión última del juez o tribunal, a quien compete de modo exclusivo la potestad jurisdiccional, la resolución de una cuestión que atañe a sus derechos e intereses y legítimos, pudiendo afectar incluso a otro derecho fundamental: a un proceso sin dilaciones indebidas. Ello implica que tal exclusión deba reputarse lesiva del derecho a la tutela judicial efectiva que a todos garantiza el art. 24.1 CE (RCL 1978, 2836) y del principio de exclusividad de la potestad jurisdiccional (art. 117.3 CE [RCL 1978, 2836]). Nuestro fallo ha de declarar, por tanto, la inconstitucionalidad y nulidad del primer párrafo del art. 102 bis.2 LJCA (RCL 1998, 1741), debiendo precisarse que, en tanto el legislador no se pronuncie al respecto, el recurso judicial procedente frente al decreto del Letrado de la Administración de Justicia resolutivo de la reposición ha de ser el directo de revisión al que se refiere el propio art. 102 bis. 2 LJCA (RCL 1998, 1741).

Una vez ha sido declarado inconstitucional el art. 102.bis.2 LJCA, se levanta la suspensión del amparo y surgen nuevas opciones ante la Sala $2^{\mathrm{a}}$ al encontrarnos frente a un recurso de amparo una vez ya ha recaído sentencia en la vía contenciosa administrativa de donde procede el acto que sirve de fundamento al amparo (recordemos que por Sentencia de 28 de abril de 2014 del Juzgado de lo Contencioso núm. 27 se estimó el recurso contencioso anulando la resolución que decreta la expulsión). No procede la retroacción al momento de la notificación del decreto resolutorio del recurso de reposición para que el interesado pueda recurrir en revisión, tal y como contempla la propia STC 63/2016 de 11 de abril, FJ. 7, en tanto el legislador no se pronuncie. Pronunciamiento este último de la Sala $2^{a}$, que nos sorprende si tenemos en cuenta que en la STC 58/2016 el TC da una solución legislativa temporal, como veremos en el punto VIII, al establecer el recurso de revisión posterior al de reposición en tanto el legislador no se pronuncie. Y, sin embargo, en este momento procesal no considera la Sala $2^{\mathrm{a}}$ que proceda la retroacción en tanto el legislador no modifique el art. 102 LJCA. No encontrando explicación coherente a dicha contradicción, lo cierto es que en el caso que nos ocupa estamos ante una resolución procesal, de señalamiento de vista que, una vez celebrada y habiendo recaído sentencia estimatoria de la pretensión del recurrente, ha perdido su objeto. En la misma línea, siguiendo la doctrina constitucional, carece de objeto alegar un derecho como es un proceso sin dilaciones indebidas cuanto estas, de haberse producido, ya han cesado al haber finalizado el pro- 
ceso judicial (STC 63/2016 de 11 de abril, FJ.3). Tampoco cabe alegar falta de agotamiento de la vía judicial como presupuesto previo para la admisión del amparo cuando ha sido el precepto que lo impide el que ha sido declarado nulo. Admitir lo contrario conllevaría limitar el acceso al amparo por no cumplir aquello que la propia ley prohíbe. La solución constitucionalmente adecuada es proceder a examinar la queja de fondo para reparar la lesión del derecho a un proceso sin dilaciones indebidas del actor, pues fue la propia ley la que impidió la intervención del magistrado-juez de lo Contencioso-Administrativo núm. 27 de Madrid en ejercicio de su función jurisdiccional de tutela de derechos fundamentales (STC 63/2016, FJ 3).

\section{DERECHO FUNDAMENTAL A UN PROCESO SIN DILACIONES INDEBIDAS}

Como hemos apuntado, la sentencia 58/2016 es consecuencia de la cuestión interna de inconstitucionalidad planteada por el TC en un recurso de amparo por violación del derecho a un proceso sin dilaciones indebidas. Siendo conscientes que la doctrina del constitucional va más allá de la cuestión de si ha habido o no dilaciones indebidas, entendemos necesario hacer una referencia a ese derecho fundamental cuya posible vulneración quedo excluida del control jurisdiccional, creando un espacio de inmunidad jurisdiccional, incompatible con la tutela judicial y la reserva de jurisdicción, que deriva en la inconstitucionalidad de la norma.

\section{DILACIONES INDEBIDAS CONSECUENCIA DEL SEÑALAMIENTO DE LA VISTA A TRES AÑOS}

El derecho a un proceso sin dilaciones indebidas es un derecho fundamental autónomo del derecho a la tutela judicial efectiva, sin que ello suponga desconocer tal y como recoge la doctrina constitucional que exista una innegable conexión entre ambos, pues el derecho a la jurisdicción contemplado en el art. 24.1 CE no puede entenderse desligado del tiempo en que la tutela judicial de los derechos subjetivos e intereses legítimos debe prestarse (STC 89/2014, de 9 de junio $)^{14}$. Para determinar si en el supuesto objeto del presen-

14 La doctrina constitucional sobre el derecho al proceso sin dilaciones indebidas puede resumirse en los siguientes términos: «El derecho a un proceso sin dilaciones indebidas es una expresión constitucional que encierra un concepto jurídico indeterminado que, por su imprecisión, exige examinar cada supuesto concreto a la luz de 
te comentario se ha vulnerado el derecho a un proceso sin dilaciones indebidas, tal y como invoca el demandante en amparo, hemos de acudir a las pautas

determinados criterios que permitan verificar si ha existido efectiva dilación y, en su caso, si ésta puede considerarse justificada, porque tal derecho no se identifica con la duración global de la causa, ni aún siquiera con el incumplimiento de los plazos procesales (STC 100/1996, de 11 de junio, FJ 2). Como se dijo en la STC 58/1999, de 12 de abril (FJ 6), el derecho fundamental referido no se puede identificar con un derecho al riguroso cumplimiento de los plazos procesales, configurándose a partir de la dimensión temporal de todo proceso y su razonabilidad. En la misma sentencia y fundamento jurídico indicamos que la prohibición de retrasos injustificados en la marcha de los procesos judiciales impone a jueces y tribunales el deber de obrar con la celeridad que les permita la duración normal o acostumbrada de litigios de la misma naturaleza con la diligencia debida en el impulso de las distintas fases por las que atraviesa un proceso. Asimismo, en coincidencia con la jurisprudencia del Tribunal Europeo de Derechos Humanos sobre el art. 6.1 del Convenio de Roma (derecho a que la causa sea oída en un tiempo razonable), que ha sido tomada como el estándar mínimo garantizado en el art. 24.2 CE afirmamos que el juicio sobre el contenido concreto de las dilaciones, y sobre si son o no indebidas, debe ser el resultado de la aplicación de las circunstancias específicas de cada caso de los criterios objetivos que a lo largo de nuestra jurisprudencia se han ido precisando, y que son la complejidad del litigio, los márgenes ordinarios de duración de los litigios del mismo tipo, el interés que en aquel arriesga el demandante del amparo, su conducta procesal y la conducta de las autoridades». En los mismos términos, SSTC 38/2008, de 25 de febrero, FJ 2; 142/2010, de 21 de diciembre, FJ 3; 58/2014, de 5 de mayo, FJ 4; y más reciente 63/2016, de 11 de abril, F 4; entre otras.

La STC 178/2007, de 23 de julio, FJ 2, recoge la jurisprudencia anterior y afirma que «la prohibición de retrasos injustificados en la marcha de los procesos judiciales impone a jueces y tribunales el deber de obrar con la celeridad que les permita la duración normal o acostumbrada de litigios de la misma naturaleza, y con la diligencia debida en el impulso de las distintas fases por las que atraviesa el proceso. Asimismo, en coincidencia con la jurisprudencia del Tribunal Europeo de Derechos Humanos sobre el art. 6.1 del Convenio de Roma (derecho a que la causa sea oída en 'un tiempo razonable'), que ha sido tomada como el estándar mínimo garantizado en el art. 24.2 CE, afirmábamos que el juicio sobre el contenido concreto de las dilaciones y, sobre si son o no indebidas, debe ser el resultado de la aplicación a las circunstancias específicas de cada caso de los criterios objetivos que a lo largo de nuestra jurisprudencia se han ido precisando, y que son la complejidad del litigio, los márgenes ordinarios de duración de los litigios del mismo tipo, el interés que arriesga el demandante de amparo, su conducta procesal y la conducta de las autoridades.» En los mismos términos, las SSTC 38/2008, de 25 de febrero, FJ 2; 93/2008, de 21 de julio, FJ 2; 94/2008, de 21 de julio, FJ 2; 142/2010, FJ 3; y 54/2014, de 10 de abril, FJ 4, entre otras. 
establecidas por la doctrina constitucional examinando cada supuesto a la luz de aquellos criterios que permitan verificar si ha existido efectiva dilación y, en su caso, si esta puede considerarse justificada, por cuanto «no toda infracción de los plazos procesales o toda excesiva duración temporal de las actuaciones judiciales supone una vulneración del derecho fundamental que estamos comentando» (STC 153/2005, de 6 de junio, FJ 2).

Centrando la cuestión a la que se ha de dar respuesta nos planteamos si el señalamiento de la vista en el PA 30/2011 para el 22 de abril de 2014, habiéndose interpuesto la demanda el 10 de diciembre de 2010, se considera excesivo. Y para ello debemos acudir al criterio objetivo de duración normal de procedimientos abreviados contra orden de expulsión por permanencia ilegal en territorio español para poder realizar un juicio sobre el contenido concreto de las dilaciones y sobre si son o no indebidas. Son numerosos los casos similares al que nos ocupa donde el retraso en el señalamiento de vistas, con una media superior a los dos años, en los procedimientos abreviados sobre orden de expulsión, ha generado su propia doctrina constitucional, elaborada de acuerdo con la del Tribunal Europeo de Derechos Humanos ${ }^{15}$. Doctrina constitucional que pasamos a resumir en los siguientes puntos aplicándola al caso que nos ocupa y teniendo presentes los criterios objetivos establecidos por el TC para valorar si concurre la denunciada vulneración del derecho a un proceso sin dilaciones indebidas (complejidad del litigio, márgenes ordinarios de duración de los litigios del mismo tipo, interés que arriesga el demandante de amparo, su conducta procesal, y la conducta de las autoridades ${ }^{16}$ :

a) siendo objeto de recurso contencioso una resolución administrativa de expulsión el asunto no revestía una especial complejidad. Teniendo en cuenta la pretensión deducida ante el órgano judicial — que ni siquiera éste califica como particularmente compleja - no parece razonable que su señalamiento y resolución se haya diferido, con evidente perjuicio del recurrente, a una fecha tan lejana, casi tres años y medio después de la interposición del recurso contencioso-administrativo. Ello ha supuesto para el demandante una larga espera antes de poder saber si podría permanecer lícitamente en España.

15 Jurisprudencia del Tribunal Europeo de Derechos Humanos que se recoge en la STC 141/2010, de 21 de diciembre (FJ4).

16 Por todas, STC 87/2015, de 11 de mayo; STC 88/2015, de 11 de mayo; STC 74/2015, de 27 de abril; STC 99/2014, de 23 de junio; STC 89/2014, de 9 de junio; STC 58/2014, de 5 de mayo; STC 142/2010, de 21 de diciembre; STC 141/2010, de 21 de diciembre. 
b) El interés que arriesga el recurrente en el pleito es el de obtener una resolución judicial que determine si era o no ajustada a derecho una resolución de la Delegación del Gobierno en Madrid que afectaba necesariamente a un ámbito preferente de sus derechos e intereses legítimos, más allá del puramente económico, relacionado con la organización de su vida familiar (hay un menor con nacionalidad española) y social, pues del sentido de la misma dependía su permanencia en España. Si bien en este punto, hay que recordar que la resolución había sido suspendida en tanto la vía judicial estuviera abierta bloqueando la ejecutividad de un acto administrativo que se presume válido.

c) En cuanto a los márgenes ordinarios de duración de los litigios, no corresponde al TC determinar en abstracto la duración razonable del procedimiento abreviado regulado en el art. 78 LJCA, pero sí puede y debe analizar en cada caso las circunstancias concretas atendiendo a los criterios señalados reiteradamente por la doctrina constitucional (STC 123/2010, de 4 de octubre). El TC ha tenido ocasión de pronunciarse, en diferentes ocasiones, sobre la vulneración del derecho a un proceso sin dilaciones indebidas con motivo del señalamiento de la vista ${ }^{17}$. Cabe advertir, por tanto, que el presente caso, con una demora de más de tres años, se inscribe también en lo que nuestra doctrina ha calificado como demora constitutiva de una dilación indebida.

d) Ha de excluirse que la conducta del demandante merezca reproche alguno, dado que, además de no haber propiciado el retraso en cuestión, interpuso recurso de reposición denunciando ante el órgano judicial la concurrencia de las supuestas dilaciones y en el que solicitó expresamente que se anticipara la fecha de celebración de la vista.

e) Finalmente, debe reseñarse que el hecho de que la demora denunciada se deba a motivos estructurales, no imputables directamente al órgano judicial, no impide apreciar la vulneración del derecho del recurrente a un

17 Numerosos son los supuestos de amparo constitucional con una media de señalamiento que supera los dos años. A modo de ejemplo citamos la STC 141/2010, de 21 de diciembre, donde la vista fue establecida para el 9 de marzo de 2010 y el recurso, contra un decreto de expulsión del territorio nacional, se interpuso el 30 de julio de 2008; en el supuesto analizado en la STC 89/2014, de 9 de junio, las fechas de la vista y de interposición del recurso, frente a una resolución de expulsión, fueron el 5 de julio de 2012 y 13 de octubre de 2009; y, por último, para terminar con los ejemplos, en la STC 54/2014, de 10 de abril la fecha del señalamiento y celebración de la vista fueron, respectivamente, el 27 de febrero de 2009 y 17 de mayo de 2011; más reciente en STC 74/2015, de 27 de abril, interpuesto el recurso el 27 de mayo de 2009 se acuerda señalar la vista para el 23 de noviembre de 2011. 
proceso sin dilaciones indebidas, pues esta situación no altera su naturaleza injustificada, según reiterada jurisprudencia del TC y del Tribunal Europeo de Derechos Humanos, en tanto que el ciudadano es ajeno a esas circunstancias ${ }^{18}$.

f) Lo anterior no se contradice con la postura del TC, en STC 58/2016 FJ 5 , que rechaza la opción, como apuntamos anteriormente, de reproducir la cuestión en el recurso contra la resolución definitiva, por carecer de sentido alegar un derecho como es un proceso sin dilaciones indebidas cuanto estas, de haberse producido, ya han cesado al haber finalizado el proceso judicial. Y decimos que no se contradice con el hecho de poder ser objeto de análisis el derecho fundamental aun cuando el proceso ya ha concluido ${ }^{19}$, pues no concurre pérdida sobrevenida de objeto, aunque

18 Como se afirma en la ya citada STC 54/2014, por referencia a la doctrina contenida en la STC 142/2010, de 21 de diciembre, "por más que los retrasos experimentados en el procedimiento hubiesen sido consecuencia de deficiencias estructurales u organizativas de los órganos judiciales o del abrumador trabajo que sobre ellos pesa, esta hipotética situación orgánica, si bien pudiera excluir de responsabilidad a las personas intervinientes en el procedimiento, de ningún modo altera el carácter injustificado del retraso. Y es que el elevado número de asuntos de que conozca el órgano jurisdiccional ante el que se tramitaba el pleito no legitima el retraso en resolver, ni todo ello limita el derecho fundamental de los ciudadanos para reaccionar frente a tal retraso, puesto que no es posible restringir el alcance y contenido de ese derecho (dado el lugar que la recta y eficaz Administración de Justicia ocupa en una sociedad democrática) en función de circunstancias ajenas a los afectados por las dilaciones. Por el contrario es exigible que jueces y tribunales cumplan su función jurisdiccional, garantizando la libertad, la justicia y la seguridad, con la rapidez que permita la duración normal de los procesos, lo que lleva implícita la necesidad de que el Estado provea la dotación a los órganos judiciales de los medios personales y materiales precisos para el correcto desarrollo de las funciones que el ordenamiento les encomienda» (FJ 6). Este es también el criterio del Tribunal Europeo de Derechos Humanos cuando en su STEDH, 7 de julio de 1989, afirmó el carácter estructural de las dilaciones sufridas por la sociedad demandante, concluyendo que esta situación no puede privar a los ciudadanos de su derecho al respeto del plazo razonable.

19 En STC 74/2015, de 27 de abril, el recurso contencioso administrativo finalizó antes de la fecha de admisión del amparo sin que por ello quede privado de objeto el proceso constitucional. Añade la STC 99/2014, de 23 de junio, en un supuesto similar al anterior, recogiendo la doctrina de la STC303/2000, de 11 de diciembre, que el hecho de haber cesado la dilación al tiempo de dictar sentencia de amparo «no significa necesariamente que el presente proceso constitucional haya quedado privado de objeto por completo, pues la presunta inactividad judicial en que se sustenta la queja de la demandante (la demora en la conclusión del período probatorio) subsistía en la fecha 
al tiempo de dictarse la sentencia resolutoria del recurso de amparo la dilación indebida denunciada ya haya cesado, «no por ello debe apreciarse que haya quedado privado de objeto el proceso constitucional de amparo, pues no puede considerarse reparada aquella mediante una actuación judicial tardía o demorada». De lo contrario, añadía el Pleno del Tribunal, con cita de la STC 141/2010, de 21 de diciembre, FJ 2 «el derecho a un proceso sin dilaciones indebidas se vería en buena medida desprovisto del contenido que le es propio, y no sería fácilmente reconocible al quedar la existencia misma de la dilación indebida al albur de la actitud del órgano jurisdiccional ante el hecho exclusivo de la interposición del recurso de amparo que, por su parte, podría correr el peligro de desnaturalizarse si se utilizara más como instrumento conminatorio

de interponerse la demanda de amparo, de modo que la resolución judicial posterior no sería capaz de reparar el eventual retraso padecido, en caso de que efectivamente se estime que se ha producido un retraso injustificado. La razón de ello debe buscarse en la autonomía, ya señalada, del derecho a un proceso sin dilaciones indebidas (art. 24.2 CE) respecto del derecho a la tutela judicial efectiva sin padecer indefensión (art. 24.1 CE), habida cuenta de que las dilaciones indebidas, en caso de existir en la fecha de presentación de la demanda de amparo (SSTC 20/1999, de 22 de febrero, FJ 1, y 146/2000, de 29 de mayo, FJ 4), no se sanan por el simple hecho de que el órgano jurisdiccional dicte tardía o demoradamente una resolución razonablemente fundada (SSTC 61/1991, de 20 de marzo, FJ 1; 180/1996, de 12 de noviembre, FJ 3; 21/1998, de 27 de marzo, FJ 2; 78/1998, de 31 de marzo, FJ 2; y 125/1999, de 28 de junio, FJ 2, por todas). El derecho a un proceso sin dilaciones indebidas no es un derecho a que se resuelva motivadamente, sino a que se resuelva en un tiempo razonable (STC 58/1999, de 12 de abril, FJ 3, y las allí citadas)». Tampoco concurre pérdida de objeto la incomparecencia de la parte al acto de la vista lo que si bien impide un pronunciamiento sobre el fondo del recurso contencioso no deja sin objeto el proceso constitucional que está ligado al excesivo lapso temporal de señalamiento de la vista (STC 99/2014, de 23 de junio). Es más, en STC 58/2014, de 5 de mayo, en el momento de dictarse sentencia estimatoria de amparo ya se había ejecutado la expulsión del territorio de España y ello no implica la desaparición de la posible lesión del derecho a un proceso sin dilaciones indebidas. De lo contrario, según ha declarado el TC, «el derecho a un proceso sin dilaciones indebidas se vería en buena medida desprovisto del contenido que le es propio, y no sería fácilmente reconocible, al quedar la existencia misma de la dilación indebida al albur de la actitud del órgano jurisdiccional ante el hecho exclusivo de la interposición del recurso de amparo que, por su parte, podría correr el peligro de desnaturalizarse si se utilizara más como instrumento conminatorio sobre el órgano judicial que como medio reparador de las lesiones que padezcan los derechos fundamentales que la Constitución reconoce y garantiza» (STC 10/1991, FJ.3). 
sobre el órgano judicial que como medio reparador de las lesiones que padezcan los derechos fundamentales que la Constitución reconoce y garantiza» (SSTC 54/2014, de 10 de abril, FJ 3, y 58/2014, de 5 de mayo FJ 3; STC 99/2014, de 23 de junio FJ 2, como antes aún el Pleno de este Tribunal, en la STC 54/2014, de 10 de abril FJ 3).

Por todo ello, cabe afirmar que se ha vulnerado el derecho a un proceso sin dilaciones indebidas del recurrente, consecuencia de la fecha fijada para la celebración de la vista. No obstante, el otorgamiento del amparo debe limitarse a la declaración de la violación del derecho fundamental, toda vez que se deduce de las actuaciones recibidas en este Tribunal que el procedimiento en cuestión ya ha concluido, habiéndose celebrado la vista acordada por el juzgado y habiendo recaído, incluso, sentencia estimatoria por el Juzgado de lo Contencioso-Administrativo núm. 27 de Madrid anulando la orden de expulsión. Se trata de un otorgamiento parcial del amparo sin que el TC pueda entrar en los problemas estructurales del funcionamiento de la Administración de Justicia (STC 141/2010, de 21 de diciembre).

Lo anterior pone de manifiesto que, si bien el señalamiento de la vista para el 22 de abril de 2014 se ajusta a lo dispuesto en el art. 182 LEC $^{20}$, no parece que logre el resultado buscado por el legislador, que al abordar la reforma de las leyes procesales más allá del objetivo primordial de desjudicialización persigue otros objetivos complementarios. Así, junto al reforzamiento de las garantías del justiciable, se hace referencia en la exposición de motivos de la Ley 13/2009 al fomento de las buenas prácticas procesales a través de mecanismos procesales como la acumulación o la tramitación de un pleito testigo que buscan evitar la multiplicidad de actuaciones para paliar las dilaciones en la tramitación de los pleitos. Para lograr este objetivo se introduce en todas las leyes procesales una nueva regulación que afecta a los señalamientos de toda

20 Como único fundamento de derecho del decreto de 26 de mayo de 2011 para desestimar el recurso de reposición contra la diligencia de ordenación de 25 de abril de 2011 de señalamiento de vista, se afirma que el señalamiento fue conforme al art. 182 LEC. Cuestión no discutida por ninguna de las partes, al tener presente un hecho objetivo como es que la demora denunciada se debe a motivos estructurales. Llama la atención que erróneamente en el citado decreto se afirma que la resolución no es firme y que cabe contra ella recurso directo de revisión en el plazo de cinco días, información al interesado que carece de mayor trascendencia que la puramente anecdótica al ser justo la no recurribilidad lo que deriva en la inconstitucionalidad del art. 102 LJCA. En todo caso "la instrucción de recursos constituye una simple información al interesado, el cual no está obligado a seguirla si la considera errónea» (STC 241/2006, de 20 de julio, FJ 3). 
clase de vistas que corresponde a los letrados de la Administración de Justicia, pero teniendo en cuenta los criterios generales y las instrucciones específicas que fije el presidente de la Sala o Sección o el titular del órgano judicial ${ }^{21}$.

La situación descrita es la que lleva, ante la existencia de una amplia serie de recursos de amparo con idéntica problemática y la existencia de una norma de dudosa constitucionalidad, a objetivar el recurso de amparo y plantear una cuestión interna de inconstitucionalidad respecto del art. 102.bis.2 LJCA. En cuanto al resultado final de la inconstitucionalidad, lo cierto es que, en sí mismo, no tiene el resultado final que persigue el interesado pues en ningún caso la invalidez del art. 102 bis, apartado 2, supone que por parte de los juzgados de lo Contencioso-Administrativo de Madrid que están sobrecargados de recursos en materia de expulsión de extranjeros vayan a señalar las vistas antes en el tiempo en tanto no se califiquen para lo sucesivo como de necesaria anteposición en la «agenda programada de señalamientos» si a ello obliga el art. 24.2 CE. No olvidemos que el derecho a un proceso sin dilaciones indebidas no supone una mejora en la atención temporal del caso por la jurisdicción, sino asegurar que se preste en términos usuales o normales.

Lo cierto es que si bien, de una parte, la inconstitucionalidad del 102 evita el espacio de inmunidad jurisdiccional, incompatible con el derecho fundamental a la tutela judicial efectiva y la reserva de jurisdicción a jueces y

21 Criterios e instrucciones en lo concerniente tanto a su organización general del trabajo como a la duración aproximada de la vista en concreto, número de señalamientos, horas de audiencia según hayan podido determinar una vez estudiado el asunto o pleito de que se trate. Los letrados de la Administración de Justicia establecerán la fecha y hora de las vistas o trámites equivalentes sujetándose a los criterios e instrucciones anteriores y gestionando una agenda programada de señalamientos y teniendo en cuenta circunstancias como la disponibilidad de la sala, el tiempo preciso para citaciones, la coordinación con el Ministerio Fiscal en los procedimientos en que las leyes prevean su intervención y la organización de los recursos humanos que se habrán de tener en cuenta y teniendo presente: el orden en que los procedimientos lleguen a estado en que deba celebrarse vista o juicio, salvo las excepciones legalmente establecidas o los casos en que el órgano jurisdiccional excepcionalmente establezca que deben tener preferencia. En tales casos serán antepuestos a los demás cuyo señalamiento no se haya hecho (art. 182.4.1 LEC; art. 63.1 LJCA). Reforma procesal en cuanto al señalamiento de vistas que ha recibido su crítica, siendo calificado por González Casso (2016) como un sinsentido creador de conflictos donde no los había al ser el señalamiento cosa de dos. El autor pone sobre la mesa la pregunta de si "¿de verdad alguien cree que de existir un recurso de revisión contra el decreto decidiendo el señalamiento de la vista, la decisión del Juez hubiera sido distinta de la del Letrado de la Administración de Justicia?». 
tribunales, y excluye que las decisiones por parte del letrado de la Administración de Justicia que puedan afectar a derechos fundamentales no sean revisables por el titular del órgano. Tal solución en tanto no se califiquen dichos asuntos como prioritarios en el señalamiento de vistas, seguirá produciéndose el retraso que en ningún caso sería imputable a la Administración, lo que nos lleva a analizar si concurren los presupuestos de responsabilidad patrimonial de la Administración de Justicia por dilaciones indebidas.

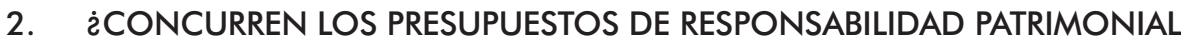 DE LA ADMINISTRACIÓN DE JUSTICIA POR DILACIONES INDEBIDAS?}

Es doctrina reiterada del Tribunal Supremo, Sala de lo Contencioso Administrativo (por todas, STS de 28 de junio de 1999, RJ 1999\6331), la que proclama que

la existencia o no de retraso constitutivo de anormalidad en el funcionamiento de la Administración de Justicia ha de valorarse, en aplicación del criterio objetivo que preside el instituto de la responsabilidad del Estado por el funcionamiento de los servicios públicos, partiendo de una apreciación razonable de los niveles de exigencia que la Administración de Justicia, desde el punto de vista de la eficacia, debe cumplir según las necesidades de la sociedad actual y para alcanzar los cuales los poderes públicos están obligados a procurar los medios necesarios. El simple incumplimiento de los plazos procesales meramente aceleratorios constituye una irregularidad procesal que no comporta, por sí misma, una anormalidad funcional que genere responsabilidad. Sí constituye anormalidad, en cambio, una tardanza, tomando en cuenta la duración del proceso en sus distintas fases, que sea reconocida por la conciencia jurídica y social como impropia de un Estado que propugna como uno de sus valores superiores la justicia y reconoce el derecho a una tutela judicial eficaz ${ }^{22}$.

22 En relación con la carga alegatoria y probatoria en la materia, la misma Sala ha señalado en reiterados pronunciamientos que la parte actora, precisamente por su posición institucional en el procedimiento, tiene la carga de llevar al Tribunal a través de las correspondientes alegaciones y pruebas la convicción acerca de la existencia de las dilaciones indebidas que denuncia, pues el órgano judicial ha de juzgar dentro de los límites de lo alegado y probado por las partes. Por todas, STS, Sala Contencioso-Administrativo, de 16 de junio de 2014 (RJ 201413952), que afirma que «la prueba ha de versar sobre lo alegado, de tal modo que carecería de sentido aportar al proceso una copiosa prueba documental si previamente no se ha cumplido con la carga de detallar en las alegaciones los hechos constitutivos de las dilaciones indebidas. Y es que, como es sabido, la existencia de dilaciones indebidas en el proceso depende de una serie de factores que ha sido desarrollada en la doctrina jurisprudencial, de tal modo que 
Jurisprudencia que se refleja en la más temprana doctrina constitucional que toma como un elemento, junto a la complejidad del litigio y la conducta de parte para valorar la existencia de infracción del derecho fundamental a un proceso sin dilaciones, la existencia de causas objetivas que comporten un retraso estructural. Los retrasos, como es el caso, debidos a defectos en la organización y falta de medios no por ello dejan de ser constitutivos de retraso anormal en el funcionamientos de la Administración de Justicia. Una tardanza de tres años entre el momento de interposición de la demanda y la fecha señalada para la celebración de la vista es percibida de modo unánime por la conciencia social y jurídica como excesiva. No se trata, tal y como apunta la Abogacía del Estado ante el TC, de expectativas de un ideal de funcionamiento que llevan a un término de comparación nada realista, pero sí de una prestación razonablemente exigible a un servicio público que no parece concurra en este supuesto.

Lo anterior no se contradice, y nadie discute, que el señalamiento de la vista se ajustó a la legalidad, art. 182 LEC y art. 78 LJCA, respetándose el orden de antigüedad en el señalamiento. Tampoco resulta discutible que la duración del procedimiento abreviado 30/2011 está dentro de la que normalmente experimentan los litigios similares, siendo doctrina constitucional que «el derecho a un proceso sin dilaciones indebidas no lo es para obtener mejoras singulares en la atención temporal del propio caso por la jurisdicción, sino para asegurar que dicha atención se preste en los términos usuales o normales, visto el tipo de asunto y demás circunstancias, términos que podrán

resulta ineludible para la actora hacer un estudio pormenorizado de las actuaciones judiciales para detectar los posibles períodos de inactividad o paralización procesal o de aquellas otras circunstancias que hayan podido contribuir a justificar o agravar retrasos excesivos en la sustanciación del pleito, y ello porque pudieran concurrir circunstancias más o menos extraordinarias que explicasen en el caso una tardanza que, "prima facie», resultara fuera de toda norma. Es por ello que la actora soporta aquella carga de estudio en detalle de las actuaciones judiciales, carga que se desdobla ya en el seno del recurso contencioso-administrativo en las facetas alegatoria y probatoria, pues ha de trasladar al Tribunal las vicisitudes procesales que ponen de manifiesto las dilaciones indebidas y además ha de probar lo alegado. Si no absuelve en debida forma aquellas cargas, ha de sufrir las naturales consecuencias que en el orden procesal se prevén a tal efecto. Ítem más, ni siquiera cabría acogerse a la duración global del procedimiento para eludir el estudio pormenorizado de las actuaciones judiciales a las que se imputan las dilaciones indebidas, que en el caso concreto podrían estar justificadas por determinadas circunstancias concurrentes, a lo que es de añadir que es preciso localizar las concretas dilaciones indebidas pues solo éstas son susceptibles de indemnización y no la duración total del procedimiento». 
o no coincidir con las expectativas que se puedan abrigar» (STC 94/2008, de 21 de julio, FJ3). Pero lo cierto es que el examen de las actuaciones, que constan en el testimonio de los autos, permite concluir que, aun cuando no ha existido una paralización absoluta de la actividad judicial, ha existido un plazo excesivo entre la interposición de la demanda y la fecha de señalamiento de la vista que en ningún caso es imputable al órgano judicial pues obedece a causas estructurales y a la carga de trabajo dado el número elevado de asuntos que pesa sobre el órgano judicial.

Sin perjuicio de lo anterior, y aun cuando se considerase la existencia de tales dilaciones concurriendo un supuesto de funcionamiento anormal de la Administración de Justicia, debe indicarse que no toda dilación indebida, acaecida en el transcurso de un procedimiento judicial, determina automáticamente la existencia de responsabilidad patrimonial, pues para ello se precisa la existencia de un daño antijurídico que guarde relación de causalidad con las dilaciones apreciadas y que sea real y efectivo y no meramente hipotético, como es el caso. Si nos detenemos en el daño que el actor invoca en la demanda de amparo, está relacionado con una situación personal y familiar delicada, unido a la inadmisión a trámite de cualquier solicitud de regularización, posible detención por las autoridades policiales e incluso eventual ingreso en un centro de internamiento. Frente a tales alegaciones hay que tener presente que el recurrente se encontraba en situación de ilegalidad en España y que el acto administrativo goza de la presunción de validez determinante de la ejecutividad del acto en tanto no sea dejado sin efecto. A fortiori la suspensión de la ejecución del acto acordada por auto del Juzgado de Instrucción núm. 14 de Madrid (de guardia) de 25 de enero de 2011, confirmada por auto de 26 de enero de 2011 del Juzgado de lo Contencioso-Administrativo núm. 27 de Madrid, garantiza la no expulsión del territorio nacional mientras esté abierta la vía judicial. Falta por tanto la realidad y efectividad en el daño ya que la parte se mueve en meras especulaciones o expectativas.

\section{VIII. ¿̇PUEDE ENTENDERSE QUE A RÁIZ DE LA SENTENCIA EL TC ACTÚA COMO LEGISLADOR AL ESTABLECER UN NUEVO SISTEMA DE RECURSOS FRENTE A LAS RESOLUCIONES DEL LETRADO DE LA ADMINISTRACIÓN DE JUSTICIA?}

La STC 58/2016, de 17 de marzo, no se limita a declarar la inconstitucionalidad y nulidad del primer párrafo del art. 102 bis.2 LJCA, lo que entra dentro de la competencia tradicional del TC como legislador negativo, sino que da un paso más allá de excluir del ordenamiento jurídico la norma inconstitucional al establecer vía sentencia un recurso ex novo de revisión para 
un supuesto no contemplado por el legislador. La literalidad de la sentencia es la que sigue: «Nuestro fallo ha de declarar, por tanto, la inconstitucionalidad y nulidad del primer párrafo del art. 102 bis. LJCA, debiendo precisarse que, en tanto el legislador no se pronuncie al respecto, el recurso judicial procedente frente al decreto del Letrado de la Administración de Justicia resolutivo de la reposición ha de ser el directo de revisión al que se refiere el propio art. 102 bis.2 LJCA».

Modesta es la intención de quien escribe de plantear si la STC recaída en la cuestión de inconstitucionalidad 5344/2013 ha logrado en palabras de García Couso (2008:21) el justo equilibrio entre la función de control de constitucionalidad y la autonomía del legislador. Parece que la respuesta va en sentido negativo, pues si bien como explica Fernández Segado (2011:187) se ha superado la concepción Kelseniana de la función del TC como legislador negativo ${ }^{23}$ y que existen diversas técnicas (sentencias interpretativas, manipulativas, aditivas) mediante las cuales la jurisdicción constitucional crea derecho, lo cierto es que en palabras del abogado del Estado ante el $\mathrm{TC}^{24}$ «no es fácil razonar de manera coherente que la decisión del constituyente de consagrar ese derecho fundamental lleve claramente implícita la necesidad de habilitar al juez o Sala de lo Contencioso-Administrativo para revisar un decreto secretarial que no acoge la reposición contra el señalamiento».

23 «La función principal de los procesos de constitucionalidad [...] es la defensa objetiva de la Constitución, al afirmar su primacía y privar de todo efecto a las leyes contrarias a la misma, excluyendo del ordenamiento a las disconformes con la Constitución (STC 14/1981, de 29 de abril, FJ 4).

24 Consecuencia de la STC 58/2016 han surgido voces críticas, esperadas por otra parte (Aragonés Seijo, 2016:67), que consideran que ha perdido sentido la distribución de competencias de la nueva oficina judicial al quedar cuestionada la utilidad del recurso de reposición y que ya se pusieron de manifiesto por el abogado del Estado ante el TC al afirmar que «en nombre de la hipotética protección del derecho al proceso sin dilaciones indebidas, se llegaría a prescribir positivamente un singular o excepcional régimen de recursos contra las diligencias de señalamiento de vistas en el procedimiento abreviado, ejercitando así una función nomotética, al crear ex nihilo una norma singular para la impugnación de las diligencias de ordenación que señalan fecha para las vistas en el procedimiento contencioso administrativo abreviado [...]. Y, junto a ello, ofrece notoria dificultad la construcción de un razonamiento convincente que permita mediar la gran distancia que existe entre la proclamación constitucional del derecho al proceso sin dilaciones indebidas y la creación ex novo de un recurso de revisión contra el decreto que desestima la previa reposición contra la diligencia de ordenamiento». 
Sin entrar a analizar los distintos tipos de sentencias que llevan al TC a crear derecho, pues excede de la pretensión del presente trabajo, baste apuntar que no está exento de numerosos problemas como pone de manifiesto Rubio Llorente (1988:49), siendo resultado, para el autor, la realidad actual de la insuficiencia de un esquema teórico inicial donde encaje la mayor aceptación de la fuerza normativa de la Constitución en la práctica cotidiana de la jurisdicción constitucional. Al TC como intérprete supremo de la Constitución (art. 1 LOTC) le corresponde determinar el sentido de cada precepto de la CE, y en esa función surge el problema del alcance de su capacidad normativa, siendo ilustrativas las palabras de García Couso (2008:3) al concretar que «el problema no radica en su posibilidad de enjuiciar la ley, que se da por sentada como presupuesto, sino en crear derecho». La doctrina admite que tras la CE el sistema de fuentes del ordenamiento jurídico español incluye la jurisprudencia del TC como fuente del derecho, teniendo el valor de cosa juzgada las sentencias del TC (art. 164 CE). Garrorena Morales (2011:188) la califica como fuente supralegal para determinar el alcance y sentido de los preceptos contenidos en la Constitución, vinculando a los demás poderes del Estado con la misma fuerza que la Constitución. Valor normativo superior de la jurisprudencia constitucional que alcanza al legislador, quien como apunta Viver Pi-Sunyer (2013:33) podrá apartarse de la doctrina del TC, pero dentro de la Constitución y nunca al margen de la misma. Lo cierto es que el TC, más allá de un legislador negativo que expulsa del ordenamiento jurídico por inconstitucionalidad y nulidad el primer párrafo del apartado 2 del art. 102. bis LJCA, en la STC objeto de estudio ejerce de legislador positivo temporal estableciendo un régimen transitorio de recursos no previsto por el legislador. Como intérprete supremo de la Constitución debe vincular la interpretación que en la sentencia da al derecho fundamental, pero no el régimen de recursos que difícilmente tiene encaje en la interpretación del derecho fundamental y menos cuando para proteger el derecho a un proceso sin dilaciones indebidas se prevé un segundo recurso ex novo que provoca el efecto contrario, esto es, alargar el proceso contencioso. Estamos ante una decisión con un determinado contenido normativo que a juicio de quien escribe no debe vincular al legislador en cuanto al sistema temporal de recursos pues nada impide que este busque un sistema de recursos alternativo al propuesto siempre que respete el sentido y alcance que el TC ha marcado en la sentencia al derecho fundamental lesionado teniendo presente que la vinculación que más allá de la parte dispositiva de la sentencia alcanza a los fundamentos de la misma, la ratio decidendi. Y que, en definitiva, supone que el legislador establezca un nuevo sistema de recursos que permita al titular del juzgado revisar una decisión del letrado de la Administración de Justicia que pueda lesionar un derecho fundamental. Una solución contraria nos llevaría a una realidad donde, 
haciendo propias las palabras de García Couso (2008:22), el TC suplantaría la actuación del legislador, de ahí que la autora «proponga cierta autolimitación de forma que sus decisiones no desfiguren el criterio de éste haciéndole decir a la ley lo que la misma no dice».

\section{REFLEXIÓN FINAL}

De la exposición que antecede podemos extraer una serie de reflexiones finales consecuencia de los distintos problemas jurídicos que se plantean. Partimos de la voluntad desjudicializadora del legislador, que en la última reforma de la legislación procesal materializa una redistribución de competencias entre jueces y letrados de la Administración de Justicia. Consecuencia de la misma, estos últimos han visto potenciadas sus competencias en materias colaterales a la función jurisdiccional, pero indispensables sin menoscabo de la potestad jurisdiccional atribuida en exclusiva a jueces y tribunales. Esta constituye un límite que, según el criterio del TC, no se respeta con el nuevo sistema de recursos contra resoluciones procesales en el orden contencioso-administrativo al privar al justiciable de la revisión por el titular del órgano judicial de una cuestión que afecta a un derecho fundamental, lo que lleva al Pleno del TC a declarar la inconstitucionalidad del primer párrafo del art. 102.bis, por afectar a derechos fundamentales cuya revisión participa de la naturaleza de la potestad jurisdiccional. Doctrina constitucional que afecta al resto de jurisdicciones y que requiere una reforma legislativa que no está exenta de debate como apunta Banacloche Palao (2016) al afirmar que la nueva doctrina del TC obliga a replantearse el modelo inicial de oficina judicial.

Como decimos, el resultado de la cuestión interna de inconstitucionalidad ha sido excluir del ordenamiento jurídico un precepto (art. 102 bis LJCA) que, en tanto no se establezca la preferencia en el señalamiento de vista respecto de los asuntos donde los demandantes arriesgan un menor interés que cuando sea objeto de recurso una resolución administrativa de expulsión del territorio nacional de un ciudadano extranjero, no evitará, por motivos estructurales no imputables al órgano judicial, el señalamiento diferido en el tiempo. De otra parte, la revisión posterior a la reposición por parte del titular del juzgado prevista por el TC no asegura que estime la pretensión del interesado de anteponer el señalamiento a otros asuntos menos urgentes.

La cuestión de inconstitucionalidad ha sido planteada por la Sala $2^{a}$ del TC en el marco de un proceso de amparo atípico dando solución a un círculo cerrado en el que se encontraba el interesado. Atípico con difícil encaje en el art. 44 LOTC al ser objeto de queja una resolución procesal del letrado de la Administración de Justicia, lo que plantea si concurren los requisitos de 
admisión del amparo. Y lo cierto es que a la vista del criterio constitucional no parece admisible una interpretación amplia que altere el régimen establecido "permitiendo convertir en objeto de amparo todo acto procedente de cualquier sujeto que se encuentre incluido en la organización judicial» (ATC de 9 de septiembre de 2013). No siendo revisables en amparo decisiones que provengan del letrado de la Administración de Justicia, resulta correcta la vía planteada por la Sala $2^{\text {a }}$ de objetivar el recurso de amparo reconduciendo el camino procesal a una cuestión interna de inconstitucionalidad respecto de la norma que impide la revisión por el titular del juzgado.

En puridad y siendo estrictamente formales podríamos defender que no concurren todos los requisitos de admisión del amparo, no solo por ausencia de acción u omisión judicial, sino también por no haberse agotado las vías procesales si tenemos presente la opción de reproducir la cuestión al atacar la resolución definitiva. Pero, ¿qué sentido tiene debatir sobre la dilación cuando ya ha tenido lugar la vista y recaído sentencia? El TC lo califica de inútil. Se nos ocurre que el único interés sea iniciar un expediente de responsabilidad patrimonial por dilaciones indebidas que busque una reparación patrimonial, pero que precisa no solo la existencia de las dilaciones, al exigirse la existencia de un daño antijurídico que guarde relación de causalidad con las dilaciones y que sea real y efectivo, lo que resulta discutible en el caso analizado.

Lo que resulta indudable es que la STC estimatoria de la cuestión de inconstitucionalidad deja tocado el sistema de recursos de la LJCA, que reproduce el régimen general de impugnación de resoluciones de los letrados de la Administración de Justicia previsto con carácter general en los artículos 451 y 454 LEC. Por tanto, sería necesario que el legislador ordinario adecuara todas las leyes procesales al criterio que ha marcado el TC. De esta manera, nos encontramos ante un TC que no se limita a expulsar del ordenamiento jurídico un precepto, sino que ejerce de legislador positivo temporal estableciendo un régimen transitorio, en tanto el legislador no se pronuncie al respecto, un régimen de impugnación no previsto en la ley sin lograr el equilibrio entre la función de control de constitucionalidad y autonomía del legislador. Es más, no se entiende que al buscar la protección del derecho fundamental a un proceso sin dilaciones indebidas se establezca la revisión posterior a la reposición con el alargamiento del contencioso que ello conlleva, salvo que tengamos presente la función garantista del TC, que busca dejar abierta la vía jurisdiccional con la revisión por el titular del juzgado previa reposición ante el secretario judicial, obteniendo un acto judicial que sí tiene encaje en el art. 44 LOTC.

Entendemos acertada la crítica de algunos autores que creen que el TC excede sus competencias constitucionales y que lleva al legislador a una situación complicada que, en caso de admitir el recurso contra todos los decretos de los letrados de la Administración de Justicia con un doble recurso, primero 
reposición y posterior revisión, implica un retraso en el procedimiento, lo que resulta un contrasentido cuando el origen del amparo es la supuesta violación del derecho al proceso sin dilaciones indebidas.

En definitiva, nada impide al legislador alejarse del camino previsto en la sentencia siempre que a la hora de pronunciarse sobre el nuevo sistema de recursos respete la interpretación que el TC ha dado al derecho fundamental y que excluye ese margen de inmunidad jurisdiccional que impide al titular del juzgado revisar decisiones del letrado que puedan vulnerar un derecho fundamental. Precisión, esta última, que sería coherente a raíz de los antecedentes expuestos que desembocan en un recurso de amparo, y así se propone por algún autor a tener en cuenta por el legislador en la reforma que a raíz de la inconstitucionalidad del art. 102 debe abordar (Font de Mora y otros: 2016), pero que puede resultar discutible si tenemos en cuenta que el TC, de forma excesiva entendemos, no limita la revisión judicial cuando está en juego un derecho fundamental, estableciendo la revisión judicial con carácter general respecto de todos los decretos definitivos del letrado que resuelven la reposición.

\section{BIBLIOGRAFÍA}

Aragonés Seijo, S., y Fernández Serra, L. (2016). La pérdida de utilidad del recurso de reposición ante el Letrado de la Administración de Justicia tras la Sentencia del Tribunal Constitucional de 17 de marzo de 2016. Diario la ley, 8749.

Banacloche Palao, J. (2016). Todas las resoluciones de los Letrados de la Administración de Justicia son revisables en todas las jurisdicciones. La inevitable extensión de la STC 58/2016, de 17 de marzo. Diario la ley, 8779.

Carrilo, M. (2008). La objetivización del recurso de amparo: una necesidad ineludible. Revista Vasca de Administración Pública. 81, 87-109.

Cremades López de Teruel, F. J. (2016). La naturaleza de la cosa: reflexiones y consideraciones a propósito de la reciente sentencia del Pleno del Tribunal Constitucional de 17 de marzo de 2016. Diario La Ley, 8753.

Escribano Testaut, P. (2013). Comentarios a la Ley de la Jurisdicción Contencioso-Administrativa. Valladolid: Lex Nova.

Fernández Farreres, G. (1994). El recurso de amparo según la jurisprudencia constitucional. Madrid: Marcial Pons.

Fernández Segado, F. (2011). El Tribunal Constitucional español como legislador positivo. Pensamiento Constitucional, 15, 127-192.

Font de Mora, J; Arribas y Atienza, P y Lozano Gago, M. (2016). Propuesta de modificación del artículo 102 bis apartado 2. ${ }^{a}$ LJCA 29/1998 de 13 de julio para cumplimiento de la STC 58/2016, de 17 de marzo. Diario La Ley, 8797. 
García Couso, S. (2008). La «normativización» de la jurisprudencia de los tribunales constitucionales. Revista General de Derecho Público Comparado, 3, 1-22.

García Murcia, J. (2001). Comentarios a la Ley Orgánica del Tribunal Constitucional. En Requejo Pagés (coord.) Madrid: BOE.

Garrorena Morales, A. (2011). Derecho Constitucional. Teoría de Constitución y sistema de fuentes. Madrid: Centro de Estudios Políticos y Constitucionales.

Martín Contreras, L. (2016), Algunas nota sobre la Sentencia del Tribunal Constitucional por la que se declara la inconstitucionalidad del artículo 102 bis de la LJCA. Diario La Ley, 8772.

De la Oliva Santos, A. (2008). La perversión jurídica del amparo constitucional en España. Actualidad Juridica Aranzadi, 751, 1-13.

Pulido Quecedo, M. (2007). La Ley Orgánica del Tribunal Constitucional anotada con jurisprudencia. Pamplona: Aranzadi.

Requejo Pagés, J. L., Duque Villanueva, J. C., Torres Muro, I. y Fossas Espadaler, E. (2009). Doctrina del Tribunal Constitucional durante el tercer cuatrimestre de 2008. Revista Española de Derecho Constitucional, 85, 227-257.

Rubio Llorente, F. (1982). Sobre la relación entre Tribunal Constitucional y Poder Judicial en el ejercicio de la Jurisdicción Constitucional. Revista Española de Derecho Constitucional, 4, 35-67.

- (1988). La Jurisdicción Constitucional como forma de creación de Derecho. Revista Española de Derecho Constitucional, 22, 9-51.

Seoane Cacharrón, J. (2016). La STC Pleno 17 de marzo de 2016 devalúa al Letrado de la Administración de Justicia y allana el camino a un proceso inquisitivo. Diario La Ley, 8752.

Ulloa Rubio, I. (2010). Comentarios a la Ley Orgánica del Tribunal Constitucional. En González Rivas, J. J. (coord.). Madrid: La Ley.

Viver Pi-Sunyer, C. (2013). Los efectos vinculantes de las sentencias del Tribunal Constitucional sobre el legislador: ¿puede éste reiterar preceptos legales que previamente han sido declarados inconstitucionales? Revista Española de Derecho Constitucional, $97,13-44$. 
